\title{
Market strategies used by processed food manufacturers to increase and consolidate their power: a systematic review and document analysis
}

\author{
Benjamin Wood ${ }^{1 *}$ (D, Owain Williams², Vijaya Nagarajan ${ }^{3}$ and Gary Sacks ${ }^{1}$
}

\begin{abstract}
Background: The public health community has become increasingly critical of the role that powerful corporations play in driving unhealthy diets, one of the leading contributors to the global burden of disease. While a substantial amount of work has examined the political strategies used by dominant processed food manufacturers that undermine public health, less attention has been paid to their use of market strategies to build and consolidate power. In this light, this paper aimed to systematically review and synthesise the market strategies deployed by dominant processed food manufacturers to increase and consolidate their power.

Methods: A systematic review and document analysis of public health, business, legal and media content databases (Scopus, Medline, ABI Inform, Business Source Complete, Thomas Reuters Westlaw, Lexis Advance, Factiva, NewsBank), and grey literature were conducted. Data extracted were analysed thematically using an approach informed by Porter's 'Five Forces' framework.

Results: 213 documents met inclusion criteria. The market strategies $(n=21)$ and related practices of dominant processed food manufacturers identified in the documents were categorised into a typological framework consisting of six interconnected strategic objectives: i) reduce intense competition with equivalent sized rivals and maintaining dominance over smaller rivals; ii) raise barriers to market entry by new competitors; iii) counter the threat of market disruptors and drive dietary displacement in favour of their products; iv) increase firm buyer power over suppliers; v) increase firm seller power over retailers and distributors; and vi) leverage informational power asymmetries in relations with consumers.

Conclusions: The typological framework is well-placed to inform general and jurisdiction-specific market strategy analyses of dominant processed food manufacturers, and has the potential to assist in identifying countervailing public policies, such as those related to merger control, unfair trading practices, and public procurement, that could be used to address market-power imbalances as part of efforts to improve population diets.
\end{abstract}

Keywords: Market strategy, Processed food manufacturers, Market power, Commercial determinants of health, Food systems

\footnotetext{
* Correspondence: bmwood@deakin.edu.au

${ }^{1}$ Global Obesity Centre, Deakin University, Melbourne, Australia

Full list of author information is available at the end of the article
}

C C The Author(s). 2021 Open Access This article is licensed under a Creative Commons Attribution 4.0 International License, which permits use, sharing, adaptation, distribution and reproduction in any medium or format, as long as you give appropriate credit to the original author(s) and the source, provide a link to the Creative Commons licence, and indicate if changes were made. The images or other third party material in this article are included in the article's Creative Commons licence, unless indicated otherwise in a credit line to the material. If material is not included in the article's Creative Commons licence and your intended use is not permitted by statutory regulation or exceeds the permitted use, you will need to obtain permission directly from the copyright holder. To view a copy of this licence, visit http://creativecommons.org/licenses/by/4.0/. The Creative Commons Public Domain Dedication waiver (http://creativecommons.org/publicdomain/zero/1.0/) applies to the data made available in this article, unless otherwise stated in a credit line to the data. 


\section{Background}

Unhealthy diets are one of the leading contributors to the global burden of disease, accounting for an estimated 11 million deaths each year and approximately $15 \%$ of all years lost to ill-health [1]. The public health community has increasingly become critical of the role of powerful private actors, such as transnational food manufacturers, in driving unhealthy diets through the shaping of food supply chains, food environments and consumer behaviour [2-5]. To date, the main focus of such work, including as part of the emerging field of the commercial determinants of health $(\mathrm{CDoH})$, has examined: the links between unhealthy food products and adverse population health outcomes; the underlying global drivers and institutional arrangements that promote corporate interests and transnationalise their activities; and the use of corporate political strategies, such as political donations, lobbying, and regulatory capture, by dominant processed food manufacturers that undermine public health policy and practice [6-10].

To date, however, the market strategies deployed by processed food manufacturers have received limited attention from the public health community. Most public health research into the market strategies of food companies has focused on the public health implications of marketing, product reformulation, and food labelling [11-18]. However, large firms are known to deploy a wide range of strategies to protect their business models and products from adverse regulation, while simultaneously building and preserving market dominance and profits [19-21]. In order to understand the ways in which companies in the food industry act to maximise profits and power, it is critical that the public health community has the tools to monitor and analyse the full range of strategies used.

Drawing on strategic management literature, 'market strategies' can be defined as concerted patterns of actions taken in the market environment for the purpose of improving corporate performance (i.e. maximising profits and shareholder returns), for example, in actions such as pricing or merger and acquisitions [19]. From the perspective of Michael Porter, who is often portrayed as the founder of modern market strategy, effective deployment of market strategies requires an understanding of the competitive structure of the industry in question $[19,22]$. For example, in an industry characterised by intense rivalry, a firm unable to compete on price may choose to instead target a new consumer segment of the market by adapting the features of its product or service to the target demographic. As another example, an incumbent firm may decide to acquire new firms that enter the market to reduce the risk of losing market share [22]. Effectively, a firm's choice of appropriate market strategies, according to Porter, involves assessing how weaknesses in the competitiveness of an industry can be leveraged in order to generate profits [21]. Such a perspective highlights the links between the deployment of effective market strategies and the potential need for government intervention to mitigate or prevent the use of strategies that restrict competition [23].

Importantly, market strategies operate in tandem with non-market strategies. Non-market strategies include a cluster of practices that are designed to improve overall corporate performance by influencing the interconnected policy, regulatory, institutional, ideological and broader socio-political structures that shape market environments $[19,24]$. In many cases, the distinction between market and non-market strategies can be artificial, as both are often collapsed into single actions or activities undertaken by firms. For example, corporate social responsibility strategies are often perceived as having both a market-strategy dimension (e.g. by increasing brand value) and a non-market strategy dimension (e.g. through gaining political and consumer legitimacy) [25]. As such, analysis of market strategies often cannot be divorced from analysis of non-market strategies, as they can be mutually interdependent and overlapping [20]. Nevertheless, considering market strategies independently and exclusively is valuable and important as a heuristic device, especially for understanding how market-based power imbalances are created or exacerbated, and, more broadly, for understanding corporate power and behaviours [26].

In this paper, we focus on the market strategies used by processed food and beverage manufacturers with concentrated and substantial market power (hereinafter dominant food companies). Many of these dominant food companies are transnational in nature, at least from a production and consumption perspective. However, there are several cases where particular companies are dominant in only one national market. In addition, it is important to highlight that markets have geographical boundaries, and regulatory agencies typically interpret market power as being confined within these boundaries [27]. The majority of dominant food companies predominately manufacture and distribute branded processed food products $[3,28]$, defined, for the purposes of this paper, as firms that process post-harvest agricultural commodities (as well as intermediate inputs from primary processing firms and/or synthetic food ingredient manufacturers) into processed foodstuffs [29]. We make a distinction between primary and secondary processors. Primary processors typically add value by processing raw agricultural commodities, such as refining grains, crushing oilseeds or slaughtering animals for meat packing [30]. Examples of prominent firms that undertake primary processing activities include JBS, Archer Daniels Midland, and Bunge. In comparison, secondary 
processors primarily add value to processed ingredients, such as corn syrup or refined sugar, by manufacturing highly processed foods [30]. Examples of prominent firms that undertake secondary processing activities include The Coca-Cola Company, the world's largest soft drink manufacturer, and Nestle, the world's largest food manufacturer that operates across a number of different processed food markets, including confectionery, ice cream, and processed dairy products [31, 32]. It is important to note that many large firms operate across functional levels in the food value chain, and many food manufacturers undertake both primary and secondary food processing activities.

In many food industries across the world, the processed food manufacturing sector is highly oligopolistic in terms of the market structure (i.e., dominated by only a few firms) and characterisable by a large number of suppliers that are only able to sell their products to a small number of dominant food companies (i.e. these constituting an oligopsony) [33]. Additionally, processed foods markets typically have substantial barriers to market entry that further consolidate the market power of incumbent firms [33].

The concentrated market power of dominant food companies is a public health concern because it confers them with the ability to promote and reinforce food value chains and food environments geared towards the production and consumption of their products, many of which are highly processed. We draw from the food classification system NOVA to support the rationale for focusing on dominant processed food companies (see Fig. 1) [34]. The NOVA system, an increasingly used food classification system in public health nutritionrelated research, categorises food products into four groups according to their level of processing [35, 36]. The first group is unprocessed and minimally processed foods. The second group is processed culinary ingredients, which includes oils, butter, sugar, lard, and salt. The third group is processed foods, which are made by adding salt, oil, sugar or other substances from the second group to foods from the first group. The fourth and final group are ultra-processed foods (UPFs), which include soft drinks, confectionery, sweet biscuits, icecream, and savoury snacks $[37,38]$. UPFs are made from combining substances derived from foods with synthetic additives, typically via a series of industrial techniques and processes. Importantly, a key feature of UPFs is that they contain food substances that are never, or at most very rarely, used in domestic kitchens, meaning that they are almost exclusively made by processed food manufacturers [34]. UPFs now amount to around half of the total dietary energy consumed in highly developed market

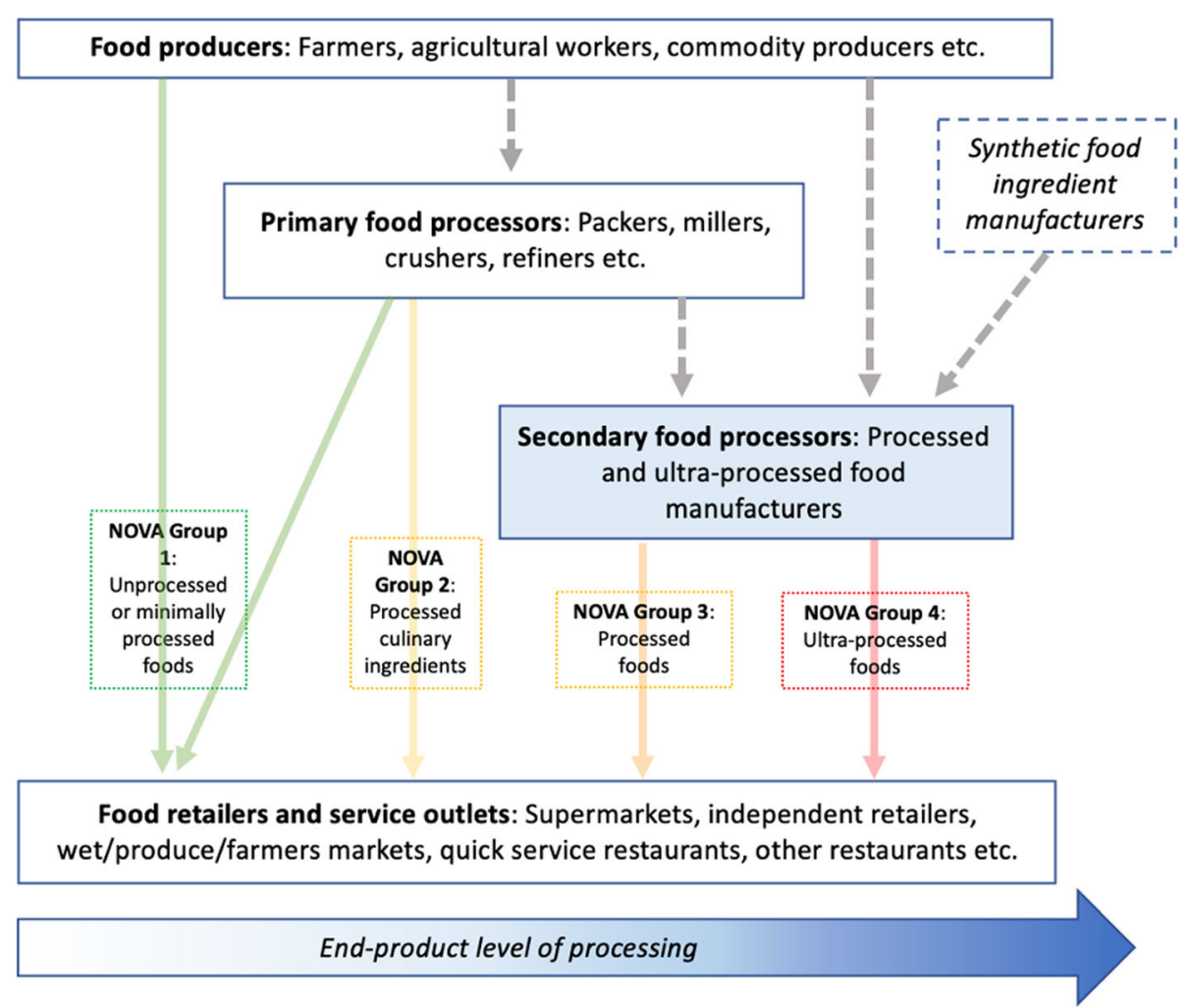

Fig. 1 A schematic conceptualisation of different pathways in the food value chain based on the level of processing of end-products 
economies, and their sales in less developed market economies are increasing rapidly [34]. Studies have shown that a greater contribution of UPFs to total energy intake are associated with poorer diet quality [3941], higher risks of all-cause mortality [42, 43], obesity $[44,45]$, and a range of diet-related chronic diseases, including depression [46-52].

A second important public health implication of the well-recognised concentrated market power of dominant food companies is that firms use their market power to generate profits in excess of what could occur in competitive markets. This accumulation of excessive material resources can, in turn, be used to fund corporate strategies and practices that undermine public health, such as lobbying, intense marketing, public relations, and the funding of scientific research and institutions $[2-4,53$, 54].

In light of the current gaps in the public health literature, the aim of this review was to systematically review the market strategies deployed by dominant processed food manufacturers to build and consolidate their power, and to develop a typological market strategy framework to inform comprehensive analysis of the market strategies and practices used by dominant processed food manufacturers from a public health perspective.

\section{Methods}

This review was undertaken in accordance with the Preferred Reporting Items for Systematic Reviews and Meta-Analyses (PRISMA) statement [55]. Original studies, reviews, commentaries, editorials, books and book chapters, working papers, online news articles, court case summaries, market research reports, and web documents from intergovernmental and non-governmental organisations were included if they met the inclusion criteria.

\section{Search strategy}

The search strategy was developed with the assistance of a specialist librarian. Preliminary search testing was conducted to find keyword search terms that captured the market strategies used by dominant food companies to exercise or consolidate market power (refer to supplementary file for detailed search strings). Public health, social sciences, and business and strategic management literature were searched via Scopus, Web of Science, Medline, Business Source Complete, and ABI Inform databases. Competition law and policy literature was searched using Thomas Reuters Westlaw and Lexis Advance. We used Factiva and NewsBank to search online news articles. A grey literature search was conducted using Google Scholar, Google Advanced Search, the market research databases Euromonitor International (Passport) and IBIS World, and a targeted search of the websites of the following intergovernmental and nongovernmental organisations: the Food and Agricultural Organization of the United Nations (FAO), the Organization for Economic Cooperation and Development (OECD), the United Nations Conference on Trade and Development (UNCTAD), the International Panel of Experts on Sustainable Food Systems (IPES-Food), and ETC Group. Finally, backward snowballing was applied in which relevant references of the identified documents were also reviewed. Databases were searched on 7 July 2020, with all results exported and duplicates removed. Grey literature searches were conducted between 8 and 10 July 2020. The first 10 pages of Google Scholar and Google were screened. Citation searches were conducted between July and September 2020.

\section{Literature selection}

The review attempted to identify documents that described or discussed the use of market strategies and practices by dominant food companies. Titles, abstracts, executive summaries and tables of contents (where relevant) were screened for all search results. Documents were included if they focused on market-based strategies used by dominant food companies, with discussion of the use of market strategies as a means of exercising power vis-à-vis other market-based actors, e.g., other food manufacturers, firms at different functional levels of the food value chain, and consumers. Documents were excluded if they were not published in English. Following screening, available full texts were retrieved, reviewed and tabulated by one of the authors.

\section{Quality assessment}

Given the diversity and multi-disciplinary nature of the data, we considered the application of standard risk of bias assessment tools, e.g. the Cochrane Handbook for Systematic Reviews [56], to be inappropriate. Instead, quality assessment was performed by categorising the sources of data into two different groups. The first group was data that were collected from peer-reviewed articles, court case proceedings and summaries, and authoritative reports from inter-governmental organisations. The second group was data sourced from all other documents, e.g., online media content, market research reports, and working papers. We considered the first group to be of higher quality given that the documents were much less likely to be subject to author bias relative to the second group.

\section{Data extraction, coding and synthesis}

Data extraction was undertaken by the lead author. Data extracted from each text included author(s), date, title, and the discussed market-based activity (or activities) undertaken by the dominant food company (or 
companies). Generalised discussions of market-based activities of dominant companies active in the food manufacturing sector were also included. The market-based activities were synthesised and categorised into practices (i.e., a specific type of activity) and strategies (i.e., a concerted set of practices deployed to attain a goal).

To inform the process of categorising the consolidated strategies and related practices, we initially developed a list of strategic objectives based on Porter's 'Five Competitive Forces' framework (hereinafter the Five Forces framework). The Five Forces framework is one of the most well-known strategic management and business frameworks [21, 22]. From a market strategy perspective, the Five Forces framework outlines how firms can select and use market strategies based on identifying and leveraging the power imbalances that exist within the market environment [23]. The five forces and their related strategic implications can be described as follows [21, 22]: i) reduce competitive rivalry through the use of strategies to reduce intense competition, especially with large rivals, and to maintain dominance over smaller rivals; ii) counter threat of market entrants by raising barriers to market entry to make it harder for new firms to enter the market; iii) counter threat of substitutes by deploying strategies that protect the firm from having their buyers switch to substitute products; iv) increase seller power by consolidating power over buyers; and v) increase buyer power by consolidating power over suppliers. We adapted the Five Forces framework for application to the food manufacturing sector by considering 'substitutes' to be substitute food products (regardless of their level of processing), 'suppliers' to be firms from upstream functional levels (e.g., food production, primary processing), and 'buyers' to be both downstream firms (e.g., retailers, food service outlets) and consumers. In addition, we separated the strategic objective to 'increase seller power' into two to take into account the differences from a public health perspective between the deployment of strategies used by dominant food companies vis-à-vis retailers and distributors compared to consumers.

The process of consolidating strategies and related practices, and categorising based on the abovementioned strategic objectives, was conducted in an iterative manner. The initial categorisations were reviewed by all of the authors, with discrepancies resolved via a consultative process. In undertaking the categorisations, we recognised that, in some cases, dominant food companies may use the same practice as part of multiple strategies, and, due to the dynamic nature of markets, the list of practices categorised under each strategy is unlikely to be exhaustive. Accordingly, the practices identified are best considered as 'illustrative'.

Summarised material was presented as a novel typological market strategy framework to inform analysis of the market strategies and related practices used by dominant processed food manufacturers to consolidate power from a public health perspective.

\section{Results}

Database searching returned 1115 results. After grey literature and snowball searching, 213 documents were included for final review (see supplementary file for PRIM $S A$ flow chart). In the evidence group considered to be of higher quality, documents included peer-reviewed articles $(n=67)$, legal case summaries $(n=24)$, and authoritative intergovernmental reports $(n=12)$. In the evidence group deemed to be of lower quality, documents included online media content $(n=60)$, market, industry or investor research reports $(n=22)$, conference papers and manuscripts $(n=15)$, non-authoritative reports $(n=10)$, completed doctoral theses $(n=3)$, and one transcribed speech.

Identified market strategies $(n=21)$ were categorised according to six interconnected strategic objectives specific to dominant processed food manufacturers: i) reduce intense competition with equivalent sized rivals and maintain dominance over smaller rivals; ii) raise barriers to market entry by new competitors; iii) counter the threat of market disruptors and drive dietary displacement in favour of their products; iv) increase firm buyer power over upstream food supply chain actors; v) increase firm selling power over downstream food supply chain actors, and vi) leverage informational power asymmetries in relations with consumers (see Table 1).

\section{Reduce intense competition with equivalent sized rivals and maintain dominance over smaller rivals}

The review identified six strategies that dominant food companies employ to reduce intense competition with large rivals and maintain market dominance over smaller rivals. Horizontal integration, achieved by acquiring a rival firm in the same product market, is an important strategy that increases a firm's market share and reduces its number of direct rivals [29, 57-61, 63-82, 239]. Horizontal acquisitions provide a substantial competitive advantage by allowing the buying firm to increase its number of brands, achieve economies of scale and economies of scope, obtain new proprietary technologies and processes, and by indirectly increasing its buyer and seller power [58-60, 240]. In some cases, the transaction value of acquisitions can be extremely large, such as the $\$ 63$ billion price tag on Heinz's takeover of Kraft Foods in 2015 [29]. The acquisition of food manufacturing firms in foreign markets is also a key means for dominant food companies to enter and penetrate new markets, especially those embedded in emerging economies [2, 3, 29, 63, 64, 71, 73, 74, 82-84, 86-92]. Dominant food companies have largely entered emerging markets via 
Table 1 A typological framework of the strategic objectives and associated market strategies and related practices used by dominant processed food manufacturers to increase and consolidate market power

\begin{tabular}{lll}
\hline Strategic Objective & Strategy & Illustrative practices \\
\hline $\begin{array}{l}\text { Reduce intense competition with } \\
\text { equivalent sized rivals and }\end{array}$ & Horizontal integration & $\begin{array}{l}\text { Acquisition of rival in the same product and } \\
\text { geographic market }\end{array}$ \\
$\begin{array}{l}\text { maintain dominance over smaller } \\
\text { rivals }\end{array}$ & Direct transnational expansion & $\begin{array}{l}\text { Direct investment in foreign markets through } \\
\text { acquisition of foreign food manufacturing firms }\end{array}$
\end{tabular}

Evidence (by group)

Group I: [29, 57-70]

Group II: [71-82]

Group I: $[2,3,29,63$ 64, 83-85]

Group II: $[71,73,74$

$82,86-92]$

Substantial investments in locally acquired firms to Group I: [2] penetrate emerging markets via boosting production and marketing capabilities

Group II: $[79,88]$

Horizontal collusion

Anti-competitive pricing strategies

Create, maintain and increase consumer demand

Develop, acquire and protect value of brands and other intangible assets
Risk-spreading arrangements with local practices to increase and protect the equity of

Exploit economies of scale (production, marketing and financial)
Explicitly collude by entering price and/or output fixing arrangements with rivals

Tacitly collude with rivals by coordinating behaviour

Risk-spreading arrangements with rivals to penetrate product markets manufacturing firms in foreign markets to penetrate new geographic markets

Exploit dominant market position to increase prices and profit margins

Anti-competitive pricing practices to push competitors out of markets, e.g. predatory pricing and territorial price discrimination

Invest in intense and aggressive marketing practices to create/maintain/increase consumer demand for branded products in new and existing markets

Segment consumer markets through marketing and price segmentation practices

Make substantial investments in marketing owned brands and brand loyalty

Build brand equity and loyalty by differentiating products based on different qualities and characteristics

Increase value of owned intangible assets via acquisition of intangible assets of other firms, and make substantial investments in product and process innovation

Protect intangible assets, including brands, through intellectual property right channels whenever possible
Increase productive efficiency and minimise marginal cost of production through practices that achieve production economies of scale
Group I: [63, 93-99]

Group II: [100-106]

Group I: $[33,96$,

107]Group II: [106]

Group I: $[29,108]$

Group II: [61, 82, 109115]

Group I: [116]

Group II: $[74,79,87$,

$114,117]$

Group I: [107, 118]

Group I: [119-124]

Group II: [125]

Group I: $[2,3,11,84$ $85,116,126-129]$

Group II: [91, 130133]

Group I: $[15,64,83$, $84,116,134,135]$

Group II: [109, 132,

133, 136-140]

Group I: $[29,58,63$, $64,118,141,142]$ Group II: [82, 132, 143-152]

Group I: [33, 64, 107 , 134, 153-156] Group II: [81, 109, 113, $117,130,132,138$ $140,146,147,157-$ 160]

Group I: $[65,66,161$ 162]

Group II: [163, 164]

Group I: $[64,165]$

Group II: [91, 166169]

Group I: $[33,58,64$ $119,161,162]$ Group II: $[79,88,132$. $147,149,150,163$, 170]

Exploit marketing economies of scale by spreading Group II: [74] large marketing budgets across a greater range of effective marketing media

Exploit financial economies of scale to make large Group I: [171, 172] 
Table 1 A typological framework of the strategic objectives and associated market strategies and related practices used by dominant processed food manufacturers to increase and consolidate market power (Continued)

\begin{tabular}{|c|c|c|c|}
\hline Strategic Objective & Strategy & Illustrative practices & Evidence (by group) \\
\hline & \multirow{7}{*}{ Supply chain control } & $\begin{array}{l}\text { capital investments and to deploy cost-cutting fi- } \\
\text { nancial strategies (e.g. transfer pricing) }\end{array}$ & $\begin{array}{l}\text { Group II: }[88,147,151, \\
152,173]\end{array}$ \\
\hline & & $\begin{array}{l}\text { Control distribution channels using trading } \\
\text { practices such as exclusive dealing arrangements, } \\
\text { predatory foreclosure, category 'captaincy', slotting } \\
\text { fees, and calendar marketing agreements }\end{array}$ & $\begin{array}{l}\text { Group I: [29, 58, 99, } \\
\text { 118, 123, 127, 153, } \\
\text { 174-182] } \\
\text { Group II: [101, 147, } \\
\text { 183-188] }\end{array}$ \\
\hline & & $\begin{array}{l}\text { Establish distribution networks in hard-to-access } \\
\text { areas }\end{array}$ & $\begin{array}{l}\text { Group I: }[135,154] \\
\text { Group II: }[147]\end{array}$ \\
\hline & & $\begin{array}{l}\text { Supply diversification and competitive sourcing to } \\
\text { secure cheap inputs }\end{array}$ & $\begin{array}{l}\text { Group I: [116, 162, } \\
\text { 189, 190] } \\
\text { Group II: [82, 132, 191, } \\
\text { 192] }\end{array}$ \\
\hline & & $\begin{array}{l}\text { Update and streamline supply management } \\
\text { practices (e.g., automation in production } \\
\text { processes) to boost productive efficiency, minimise } \\
\text { transaction costs and promote product } \\
\text { differentiation }\end{array}$ & $\begin{array}{l}\text { Group I: }[155,193- \\
\text { 195] } \\
\text { Group II: [82, 147, } \\
\text { 196-198] }\end{array}$ \\
\hline & & $\begin{array}{l}\text { Control ancillary activities by acquiring firms and } \\
\text { related assets in ancillary industries, e.g. business } \\
\text { management services, storage and transport } \\
\text { industries }\end{array}$ & $\begin{array}{l}\text { Group I: }[162,199] \\
\text { Group II: }[200]\end{array}$ \\
\hline & & $\begin{array}{l}\text { Substantial investments in Big Data platform } \\
\text { technologies to acquire, control and manipulate } \\
\text { large amounts of supply chain and consumer } \\
\text { related information }\end{array}$ & Group II: $[132,201]$ \\
\hline \multirow[t]{8}{*}{$\begin{array}{l}\text { Counter the threat of market } \\
\text { disruptors and drive dietary } \\
\text { displacement in favour of their } \\
\text { food products }\end{array}$} & \multirow[t]{4}{*}{$\begin{array}{l}\text { Product diversification (increase } \\
\text { economies of scope) }\end{array}$} & $\begin{array}{l}\text { Acquisition of firms in substitute product markets } \\
\text { (domestic or cross-border) }\end{array}$ & $\begin{array}{l}\text { Group I: }[29,57,58 \\
63,107,156,171,202] \\
\text { Group II: [32, 74, 79, } \\
88,89,109,159,164 \\
167,203-206]\end{array}$ \\
\hline & & $\begin{array}{l}\text { Acquisition of firms in related (e.g. healthcare, pet } \\
\text { food) or unrelated industries (conglomerate) }\end{array}$ & $\begin{array}{l}\text { Group I: }[107,108, \\
\text { 207] } \\
\text { Group II: [72, 109, } \\
208]\end{array}$ \\
\hline & & $\begin{array}{l}\text { Substantial investments in the development of } \\
\text { new products in response to consumer trends }\end{array}$ & $\begin{array}{l}\text { Group II: [32, 206, } \\
\text { 209] }\end{array}$ \\
\hline & & $\begin{array}{l}\text { Enter and penetrate related product markets } \\
\text { through strategic alliances, joint ventures and co- } \\
\text { branding agreements }\end{array}$ & $\begin{array}{l}\text { Group I: [210] } \\
\text { Group II: [74, 109, 113, } \\
\text { 211] }\end{array}$ \\
\hline & Control market disruptors & $\begin{array}{l}\text { Operate as venture capitalists and business } \\
\text { incubators in order to eliminate the threat of start- } \\
\text { ups and capitalise on and internalise successful } \\
\text { start-ups }\end{array}$ & Group ॥: [109, 206] \\
\hline & \multirow{3}{*}{$\begin{array}{l}\text { Drive dietary displacement and } \\
\text { adaption in favour of branded } \\
\text { processed foods over } \\
\text { alternatives }\end{array}$} & $\begin{array}{l}\text { Engineer hyperpalatable, quasi-addictive, and aes- } \\
\text { thetically and texturally pleasing foods }\end{array}$ & $\begin{array}{l}\text { Group I: }[2,34,85, \\
\text { 129, 154, 212] } \\
\text { Group II: }[213,214]\end{array}$ \\
\hline & & $\begin{array}{l}\text { Drive changes in food consumption habits, e.g. } \\
\text { promotion of snacking over regular meals, that } \\
\text { favour the consumption of branded processed } \\
\text { foods }\end{array}$ & Group I: [85] \\
\hline & & $\begin{array}{l}\text { Keep price of branded products low in value- } \\
\text { based food markets by taking advantage of econ- } \\
\text { omies of scale and cheap commodity inputs }\end{array}$ & $\begin{array}{l}\text { Group I: }[2,3,129] \\
\text { Group II: }[91]\end{array}$ \\
\hline \multirow[t]{2}{*}{$\begin{array}{l}\text { Increase firm buyer power via } \\
\text { exercising power over upstream } \\
\text { food supply chain actors }\end{array}$} & Vertical integration (backwards) & Acquisition of upstream firms and related assets & $\begin{array}{l}\text { Group I: }[58,63,107 \\
\text { 194, 195, 215, 216] } \\
\text { Group II: }[132,217]\end{array}$ \\
\hline & Vertical control (backwards) & Control access to and use of inputs, e.g. land, & Group I: $[29,33,58$, \\
\hline
\end{tabular}


Table 1 A typological framework of the strategic objectives and associated market strategies and related practices used by dominant processed food manufacturers to increase and consolidate market power (Continued)

\begin{tabular}{|c|c|c|c|}
\hline Strategic Objective & Strategy & Illustrative practices & Evidence (by group) \\
\hline & & $\begin{array}{l}\text { production-related plant and equipment, crop var- } \\
\text { ieties, water }\end{array}$ & $\begin{array}{l}\text { 64, 141, 195, 218] } \\
\text { Group II: }[102,201 \\
217,219,220]\end{array}$ \\
\hline & & Use private standards to control upstream firms & $\begin{array}{l}\text { Group I: [29, 190, 221, } \\
\text { 222] } \\
\text { Group II: [132] }\end{array}$ \\
\hline & & $\begin{array}{l}\text { Exert power over suppliers through the use of } \\
\text { unfair contract agreements }\end{array}$ & $\begin{array}{l}\text { Group I: }[29,58,189, \\
\text { 223, 224] } \\
\text { Group II: }[225,226]\end{array}$ \\
\hline & $\begin{array}{l}\text { Vertical coordination } \\
\text { (backwards) }\end{array}$ & $\begin{array}{l}\text { Coordinate upstream activities through risk- } \\
\text { spreading arrangements (e.g., strategic alliances } \\
\text { and joint ventures) with upstream firms }\end{array}$ & $\begin{array}{l}\text { Group I: }[64,108,227, \\
\text { 228] } \\
\text { Group II: }[82,217,229 \text {, } \\
\text { 230] }\end{array}$ \\
\hline \multirow[t]{4}{*}{$\begin{array}{l}\text { Increase firm seller power via } \\
\text { exercising power over downstream } \\
\text { actors }\end{array}$} & Vertical integration (forwards) & $\begin{array}{l}\text { Acquisition of downstream firms and related } \\
\text { assets }\end{array}$ & $\begin{array}{l}\text { Group I: [107, 153, } \\
\text { 195, 215] } \\
\text { Group II: [187, 198, } \\
\text { 231] }\end{array}$ \\
\hline & Vertical control (forwards) & $\begin{array}{l}\text { Control distribution channels using practices such } \\
\text { as exclusive dealing arrangements, loyalty rebates, } \\
\text { product bundling, resale price maintenance, and } \\
\text { territorial supply contracts }\end{array}$ & $\begin{array}{l}\text { Group I: [99, 174, 181, } \\
\text { 232] } \\
\text { Group II: [124] }\end{array}$ \\
\hline & Vertical coordination (forwards) & $\begin{array}{l}\text { Coordinate downstream processes and activities } \\
\text { through risk-spreading arrangements }\end{array}$ & $\begin{array}{l}\text { Group I: }[228,233] \\
\text { Group II: }[206]\end{array}$ \\
\hline & Vertical collusion & $\begin{array}{l}\text { Collude with retailers to set up price-fixing ar- } \\
\text { rangements of branded products }\end{array}$ & $\begin{array}{l}\text { Group I: [63] } \\
\text { Group II: [103] }\end{array}$ \\
\hline \multirow[t]{2}{*}{$\begin{array}{l}\text { Leverage informational power } \\
\text { asymmetries in their relations with } \\
\text { consumers }\end{array}$} & $\begin{array}{l}\text { Drive demand within vulnerable } \\
\text { consumer groups }\end{array}$ & $\begin{array}{l}\text { Target vulnerable population groups with } \\
\text { integrated marketing communication practices } \\
\text { and use of multiple marketing channels, especially } \\
\text { digital channels }\end{array}$ & $\begin{array}{l}\text { Group I: }[11,13-16, \\
234]\end{array}$ \\
\hline & $\begin{array}{l}\text { Exploit product and process } \\
\text { related information asymmetries }\end{array}$ & $\begin{array}{l}\text { Withhold, manipulate or use misleading process } \\
\text { and product-related information on food labels via } \\
\text { practices such as the use of deceptive health and } \\
\text { nutrition claims, misleading marketing claims (e.g. } \\
\text { unfinished or irrelevant claims), and greenwashing }\end{array}$ & $\begin{array}{l}\text { Group I: }[33,235-237] \\
\text { Group II: }[140,238]\end{array}$ \\
\hline
\end{tabular}

acquisitions, strategies that are often in response to stagnating sales revenue in their home markets [2, 3, 29, 91, 92, 116]. Following entry, dominant food companies often further penetrate emerging markets by investing substantial amounts of capital in boosting production and marketing capabilities $[2,79,88,116]$.

It was identified that dominant food companies also undertake risk-spreading arrangements, such as strategic alliances, licensing agreements, franchising agreements, and joint ventures, in order to penetrate both new and existing product and geographic markets [61, 74, 79, 82, $86,87,109,110,112,114-116]$. One noteworthy example is the joint venture Cereal Partners Worldwide, created in 1991 between Nestlé and General Mills, which at the time united the marketing capacity of Nestle with the production know-how of General Mills to penetrate the global breakfast cereal market (to the detriment of Kellogg) [162]. Moreover, risk-spreading arrangements with local manufacturing firms can allow dominant food companies to enter new geographic markets without the need to make big and often risky investments, while still being able to benefit from local distribution channels, manufacturing capabilities, and market/consumer/regulatory knowledge. Many dominant food companies, as global brand owners, can also decide to use licensing agreements - whereby they permit local firms to manufacture and distribute a branded product within a specified region - to generate revenue without taking the risk of investing in local manufacturing or distribution activities [61, 64, 79, 111, 113].

The review identified cases where dominant food companies have resorted to collusion to reduce intense competition and maximise profits. Despite explicit collusion being illegal in many national legal systems, a number of cases were identified in which dominant food companies were reported to have entered price and/or output fixing arrangements, forming cartels with rivals in the same product market [33, 63, 93-107]. In 2008, a German court found that a number of large branded chocolate manufacturers, including Kraft Foods and Alfred Ritter, 
had colluded to coordinate a series of price increases in some cases around 15-25\% - in the German market [98]. Explicit collusive practices, such as the sharing of sensitive market information, are not specific to illegal cartels and can be facilitated through legal channels such as trade groups and associations $[63,101]$. However, collusion in processed food markets has been shown to often be tacit, rather than explicit. Tacit collusion usually occurs in concentrated markets, such as carbonated soft drink markets, when large rivals that compete over time and across regions repeatedly interact and thus begin to anticipate one and another, allowing them to coordinate behaviour with little or no direct communication [33, 96, 106, 107].

It was revealed that dominant food companies at times use a number of anti-competitive pricing strategies as a means of maintaining market dominance over smaller rivals. Food companies in positions of market dominance were shown to exploit their 'price making' capabilities in which they set prices without having to make reference to the pricing strategies of rivals $[107,118]$. In such cases, dominant firms can choose to set their prices high in order to increase profit margins to levels higher than what would be possible under genuinely competitive conditions. Conversely, dominant firms can also set their prices at very low levels to force out would-be competitors. This practice, known as predatory pricing, occurs when dominant firms set prices at very low levels, at times even below the marginal cost of production, for extended periods of time to drive out smaller rivals lacking the power to absorb consequent losses [119, 121, 124, 125]. Similarly, some dominant food companies were shown to employ a practice called territorial price discrimination, whereby predatory prices employed in certain geographical markets are offset by setting higher prices in other markets where the targeted rivals are not active [120, 122].

Dominant food companies are able to leverage their greater financial, production and market power relative to smaller rivals by making substantial investments in a range of practices that increase consumer demand for their branded products. It is important to note that the use of this market strategy also raises barriers to market entry, and as such, links with strategies discussed in the next section (refer to 3.2. Raise barriers to market entry by new competitors). Dominant food companies reportedly spend enormous amounts of money on intense and aggressive marketing, including product placements and price promotions. This maintains consumer demand for their branded products in existing markets, as well as creating and increasing demand in new markets [2, 3, $11,84,85,91,116,126-130,132,133]$. Furthermore, relative to smaller food manufacturers, dominant food companies tend to be able to negotiate more advantageous product placement and trade promotion agreements with retailers [127].

Similarly, dominant food companies often have the necessary resources to aggressively pursue market segmentation strategies, especially in relation to developing niche markets $[15,64,83,84,109,116,120,132,133$, 135-140]. This strategy involves segmenting different groups of consumers with differentiated products and targeted marketing based on their demographics (e.g. children), income and economic status (e.g. lower income groups), psychographics (e.g. consumer beliefs, values, motivations, priorities) and behavioural characteristics (e.g. purchasing behaviour). Market segmentation can also have a geographic dimension, for example, as evidenced by dominant food companies investing substantial amounts of money into adapting their global brands to the local tastes and habits of different consumer groups around the world, a process often captured by the term 'glocalisation' [82, 83, 116, 137]. Furthermore, market segmentation permits firms to tier or differentiate prices, maximising sales and profits by gearing prices to the different abilities to pay across national markets.

\section{Raise barriers to market entry by new competitors}

The review identified three broad strategies used by dominant food companies to raise barriers to market entry in order to prevent unwanted competition, consolidate market power, and facilitate profit maximisation. The identified strategies were developing, acquiring and protecting the value of their brands and other intangible assets; exploiting production, marketing and financial economies of scale; and obtaining supply chain control.

Dominant food companies often invest substantial amounts of capital in increasing and protecting the value of their brands, often referred to as brand equity $[29,58$, $63,81,82,118,132,141-143,146,148-152]$. For some perspective, The Coca-Cola Company's (TCCC) brand portfolio was valued at US\$63.4 billion in 2019 [241]. Building a brand is costly and time consuming, giving incumbent firms with existing brand loyalty an enormous advantage over new market entrants [33, 82, 132]. Brand equity is also crucial for dominant food companies to maintain bargaining power over large supermarkets, given that 'must stock' brands are much less likely to displaced by supermarket own brands compared with the lesser known brands of smaller food manufacturers [64, 141, 143-145].

A critical aspect of developing and protecting brand equity is product differentiation [33]. Product differentiation describes a strategy of differentiating a firm's products from those of existing or potential rivals. This is achieved by differentiating products based on characteristics such as taste, convenience, appearance, production 
processed, healthfulness, marketing arrangements, and the ecological implications of production and consumption $[33,64,81,86,107,109,113,130,132,134,138$, $140,146,147,153-160]$. For effective product differentiation to occur, product consistency is vital. In this respect, dominant food companies have the resources and supply chain control to ensure a large, consistent supply of products that can fulfil specified external or in-house quality standards [33].

Beyond brand equity, dominant food companies invest substantial amounts of money to develop and acquire other types of intangible assets. This includes new product and process innovations (such as inorganic microcoatings on candy, or the fortification of foods using nano-capsules), brand and packaging designs, and formulas. In some circumstances, these intangible assets can be protected through intellectual property rights channels, conferring a significant long term advantage to the firm [64, 91, 165-169].

Another key barrier to market entry in many processed food markets is the fact that dominant food companies have managed to establish economies of scale in terms of production, marketing and finance. Production economies of scale - achieved through practices such as the acquisition of other firms, large-scale investment in existing production facilities, and investing in advanced process innovations (e.g., automation) - can optimise production efficiency and minimise the marginal cost of production [33, 58, 64, 119, 132, 147, 149, 150, 161163]. Dominant food companies also make use of marketing economies of scale in which they can lower the costs of marketing practices by spreading their marketing budget across a range of different and effective marketing media [74]. Regarding financial economies of scale, dominant food companies are often able to exploit their ability to access and afford large amounts of cheap capital to make large capital investments [151, 171]. In addition, dominant food companies with subsidiaries in different countries can readily mobilise capital across borders, enabling them to undertake practices such as transfer pricing - namely the trading of goods or services between subsidiaries - in order to minimise tax obligations and maximise financial returns [152, 172, 173]. A core financing strategy of Nestlé, for instance, was described in the literature as locating its trademarks and patents in Switzerland, its home jurisdiction, in order to set up transnational intra-firm royalty payment streams designed to assist the repatriation of profits in tax-effective ways [172].

The ability of dominant food companies to control the processed food supply chain (i.e., 'supply chain control') is another important barrier to market entry. For instance, it was identified that dominant food companies often leverage their market power vis-à-vis retailers in order to control distribution channels, including retail shelf space in supermarkets. An example of a related trading practice used by dominant food companies is exclusive dealing arrangements, which entails the placement of restrictions on how much rival product the retailers/distributors are allowed to sell $[29,99,123,153$, $174,177,181,185,186,188]$. In some contexts, dominant firms can also aim to be given 'category captaincy', which refers to the situation when retailers give food manufacturers leading category management roles, allowing them to arrange and control retail shelf space $[118,178,182,184,187]$. Similarly, dominant food companies can make payments for optimal retail positions, known as slotting fees, as well as undertaking calendar marketing agreements, which are payments for preferential treatment by retailers, such as exclusive in-store advertising, during a specified period of time [58, 101, 175, $176,179,180,183]$. As a case in point, the European Commission made the decision to address certain trading practices used by TCCC to control distribution channels in an anti-competitive manner, which included forcing a number of distributors to deny access to TCCC's rivals and using financial incentives to reserve a certain part of retail shelf space dedicated to carbonated soft drinks [181, 242]. Dominant food companies, compared with food manufacturers with less market power, were also described as being able to negotiate more advantageous in-store promotional arrangements with retailers [127].

Given their integration into and access to input markets in different markets around the world, dominant food companies have the ability to pursue supply diversification and competitive sourcing as a means of securing cheaper supplies [82, 116, 132, 162, 189-192]. Additionally, dominant food companies often take advantage of advanced supply chain management practices - such as the use of enterprise resource planning software, and automation innovations in quality management and production - to minimise transaction costs, increase production efficiencies, and ensure product quality and differentiation. Dominant food companies were seen to also acquire or control firms in ancillary industries, such as those involved with storage and refrigeration [82, 147, 155, 193-198]. TCCC, for example, deployed this strategy in its acquisition of a firm involved in the production and distribution of refrigeration units in the European Common Market [199]. Finally, an important supply chain control strategy that can raise barriers to market entry is the ability to obtain, control, and manipulate consumer, market and supply chain-related information. A key means to achieve this was reported as being the use of costly Big Data platform technologies that mine, store and interpret vast amounts of consumer data [132, 201]. 
Counter the threat of market disruptors and drive dietary displacement in favour of their products

The review identified three strategies used by dominant food companies to counter the threat of substitute food products: product diversification; control market disruptors; and drive dietary displacement and adaption in favour of branded processed foods over alternatives. The two main groups of substitute products relative to the food products made by dominant food companies were newly developed food products, especially those developed in response to changing consumer trends (e.g. plant-based protein meat and dairy product alternatives), and foods that form part of traditional diets, many of which are unprocessed or minimally processed.

In many cases, the branded products of dominant food companies are also in competition with private label food products across many processed food markets. Private label (eg. supermarket 'own-brand') food products are those that are manufactured by a third-party or contract food manufacturer and sold under a retailer's name. Given that private label products in the same market are technically rival products (that typically compete on price), rather than substitute products per se, we did not include strategies deployed by dominant food companies to counter the threat of private label companies under this strategy as they are addressed as part of other strategies. For example, several studies discussed that dominant food companies with strong brands are likely to be at a lower risk of losing market share to private labels compared with small food companies with lesser known brands [64, 141, 143-145]. Furthermore, in certain contexts, dominant food companies may choose to become a third-party manufacturer for a retailer as part of risk-spreading arrangement (a practice that falls under the horizontal collaboration strategy) [243].

A range of product diversification practices were identified during the review, including investing large amounts of money into developing new products [32, 206, 209]; in acquiring firms in substitute markets (e.g. a soft drink manufacturer acquiring a bottled water manufacturer); or by acquiring new brands, especially those linked with being 'natural', 'healthy', 'sustainable', or 'organic' $[29,32,57,58,63,74,79,88,89,107,109,156$, $159,164,167,171,202-206]$. Similarly, dominant food companies can also enter substitute markets via strategic alliances or joint ventures, either with large rivals or emerging firms $[74,109,113,210,211]$.

In order to mitigate the risk of market disruptions, a number of dominant food companies were seen to operate as venture capitalists and company incubators, especially in relation to start-up food technology firms [109, 206, 229]. Indeed, a large number of new firms entering processed food markets are funded by the in-house venture capital programs of dominant food companies, e.g., Nestle's Terra Accelerator and The Unilever Foundry $[109,206]$. The financing role means the large firms are then able to cherry pick and internalise the most successful start-up firms.

Dominant food companies pursue a number of strategies in order to drive dietary displacement away from traditional foods towards their branded processed food products. In addition to increasing consumer demand for their products via intense and aggressive marketing (refer to section 3.1), dominant food companies invest in marketing practices to drive changes in consumption habits, such as the promotion of snacking over regular meal times [85]. Dominant food companies also invest substantial amounts of money into engineering hyperpalatable, quasi-addictive, and aesthetically and texturallypleasing food products [2, 34, 85, 129, 154, 212-214]. For example, a key purpose of their research and development programs is to identify 'bliss points' for certain food components (e.g., sugar, salt, fat, and certain additives) in their products in order to optimise consumer pleasure [212-214]. Finally, dominant food companies can take advantage of their production economies of scale, as well as their ability to access cheap commodity inputs, to keep the consumer price of their branded processed food products below that of alternative products $[2,3,91,129]$. This strategy is particularly important in food product markets in which price plays a key role in the purchasing decisions of consumers.

\section{Increase firm buyer power by exercising power over upstream actors}

It was seen during the review that dominant food companies exercise power over upstream actors in the food supply chain using three related strategies: integration, control and coordination. Dominant food companies vertically integrate 'backwards' by acquiring upstream firms, including food production firms and primary food processors [58, 63, 107, 132, 195, 215, 217]. 'Backwards' vertical control can be achieved via the imposition of contract agreements $[29,58,102,189,223-226]$. In some cases, contract agreements are designed to allow dominant buyers to impose unfair conditions on their suppliers, such as permitting the buyer to make unilateral or retroactive changes to the contract [224].

Dominant food companies were also revealed to use private standards relating to food quality, safety or sustainability as a means of exerting power over their suppliers [29, 132, 190, 221, 222]. Private standards, referring to standards imposed by one private actor on another without the involvement of government, can at times have detrimental effects on small-scale producers. As an example, private standards enforced by Nestle and Parmalat relating to the handling and storage of milk 
forced thousands of dairy farmers in Brazil out of business, largely because they could neither afford nor access the necessary capital and technology to fulfil the newly imposed private standards [132]. In addition, dominant food companies were revealed to control access to and use of key inputs, such as land, seeds of certain crop varieties, farming equipment, and water $[29,33,58,64,141$, 195, 217-220]. Lastly, the coordination of upstream processes and activities can be achieved through the use of risk-spreading arrangements with upstream firms [64, 82, 108, 227-230].

\section{Increase firm seller power by leveraging power over food retailers and distributors}

The review identified that the key strategic approaches for dominant food companies to increase their selling power vis-à-vis downstream actors - that is, the distributors and retailers of their branded products - involved vertical integration, control, coordination, and collusion. 'Forward' vertical integration is achieved when dominant food companies acquire a retail or distribution firm, or the distribution-related assets of smaller distributors (e.g., dispensing equipment, fridges, and vending machines) [107, 153, 187, 195, 198, 215, 231]. Vertical control over downstream actors can be achieved via a number of trading practices. Some of these trading practices clearly exploit power imbalances and are thus considered unfair to the buyer. Important examples include the use of exclusive dealing arrangements and loyalty rebates to control what the upstream actors can sell [99, 174, 181]; the use of 'product bundling' (sometimes referred to as tying) to force buyers to purchase an unwanted product [244]; the use of resale price maintenance, which occurs when manufacturers control the retail price [99]; and the use of territorial supply contracts, in which restrictions are placed on crossborder sourcing, preventing the upstream actor to source the same goods from other national markets where they are cheaper $[99,232]$.

In a similar fashion to both horizontal and backwards vertical coordination, forward vertical coordination occurs when dominant food companies partake in risk-spreading arrangements with upstream actors in order to better coordinate the distribution of their branded products $[206,228,233]$. Finally, the review identified evidence of dominant food companies colluding with upstream actors by entering into pricefixing arrangements for their branded processed food products [63, 103]. A notable example was the branded bread price-fixing scheme that occurred in Canada between 2001 and 2016 in which colluding firms agreed to coordinate price increases on at least 15 occasions [103].

\section{Leverage informational power asymmetries in their relations with consumers}

The review identified a number of important ways that dominant food companies leverage information-based power asymmetries over consumers. Although it could be justified that all forms of intense and aggressive marketing communications are an expression of power by a firm over a consumer, we primarily focused on strategies and practices described as being exploitative and misleading in nature primarily from a consumer law perspective.

It was revealed that dominant food companies often use marketing practices that specifically target vulnerable population groups $[13-16,234]$. As a pertinent example, dominant food companies were reported to have used sophisticated integrated marketing communication practices - combining communication practices such as marketing, advertising, promotions, and public relations - to target young children who do not have the cognitive ability to understand and evaluate marketing strategies $[14,15]$. Moreover, on occasions, dominant food companies were reported to bombard children through the simultaneous use of multiple marketing channels, such as TV ads, in-school marketing, product placements in popular programs and movies, and online platforms $[15,16]$. The use of online platforms can be particularly exploitative given that large firms are able to collect and use extensive amounts of personal data from young internet users to deliver behavioural-based precision marketing [11]. Another vulnerable population group that dominant food companies were shown to target, predominately through outdoor advertising practices, were people living in lower income neighbourhoods [13, 234].

The review identified a number of cases in which dominant food companies were shown to have taken advantage of informational asymmetries over consumers in relation to food labelling, composition and production processes. Such information based power asymmetries are of notable concern given that product and processrelated information cannot easily be found or verified by consumers upon consumption [33, 235, 236]. A number of practices were identified that were considered misleading under consumer law. For instance, the use of misleading representations was reported, including the use of the phrase 'school canteen approved' [236]. The use of misleading health claims was also observed, such as Heinz's claim in the Australian market that one of their products was healthy and nutritious for children, a claim that was subsequently proven to be inaccurate [237]. The alleged use of misleading food composition was also identified in a case in which a dominant food company's 'pomegranate-blueberry' juice beverage was found to contain more than $99 \%$ apple and grape juice 
[235]. Furthermore, it was reported that dominant food companies often use a range of marketing practices on packaging in order to influence consumer purchasing behaviour, such as the use of words with no legal or formal meaning (e.g. natural), the use of unfinished claims (e.g., '25\% less added salt' without stating a comparator), irrelevant claims, the use of healthy sounding brand names (e.g. 'Go Natural'), and the use of 'greenwashing' labels (i.e., the practice of marketing a product as being ethical and ecologically friendly without it truly being so) $[140,238]$.

\section{Key cross-cutting practices used to achieve multiple strategic objectives}

A number of key cross-cutting practices were identified that can be deployed by dominant food companies to achieve multiple strategic objectives. First, the acquisition of other companies or their assets can fulfil different strategic objectives depending on the type of transaction (e.g., horizontal, vertical) and its geographical boundaries (i.e. domestic, transnational). Second, and in a similar manner to firm acquisition, partaking in risk-spreading arrangements (e.g., joint ventures) with other firms can be used to achieve a number of strategic objectives. Third, investing substantial amounts of money into integrated marketing communications can be used to increase consumer demand relative to rivals, drive dietary displacement away from alternative food products, and raise barriers to market entry. Fourth, investing substantial amounts of money into product and process-related research and development and where possible, protecting developed assets via through intellectual property channels, can reduce rivalry by creating new market segments and heighten barriers to market entry. Fifth, collusion can achieve different strategic objectives depending on the parties involved in the arrangement. Finally, the control and manipulation of consumer and supply chain related data can be used to fulfil different strategic objectives depending on which market-based actors are exploited by the resulting informational asymmetries.

\section{Discussion}

The paper identified a number of market strategies and related practices used by dominant food companies to consolidate their power, and categorised these strategies according to six interconnected strategic objectives. Effectively, these six strategic objectives outline how market strategies can be deployed by dominant food companies to leverage power asymmetries within the market environment, especially over consumers, smallscale food producers, smaller manufacturing rivals, and small-scale retailers and distributors. The strategies were identified from a diverse range of literature, including public health, social sciences, competition law and policy, and business and strategic management. The evidence quality and risk of bias of the data sourced from the identified documents were assessed using a novel approach, in which data collected from peer-reviewed articles, court case proceedings, and authoritative reports from inter-governmental organisations were considered to be of higher quality than data sourced from online media content, market research reports, and working papers.

\section{Public health implications of market strategies used by dominant food companies}

There are three broad and interconnected manifestations of public health concern that result from market-based power imbalances that favour dominant food companies: i) the ability to generate profits from anti-competitive behaviour that can then be used to fund corporate practices that undermine public health; ii) the ability to shape retail food environments in ways that promote consumption of unhealthy foods and beverages; and iii) the ability to structure food supply chains that are geared towards the production of cheap inputs used in the manufacturing of unhealthy processed food products. Critically, these public health concerns do not rely on an assumption that smaller, less powerful companies are likely to be more public health conscious. Instead, a central argument for limiting market-power in this area is that smaller, less powerful companies are likely to lack the material resources, capacity and co-ordination required to undermine public health in such a systematic way.

First, and fundamentally, dominant food companies can leverage their market power vis-à-vis all marketbased actors to generate and accumulate profits in excess of what would be possible in competitive market environments. The implications of this, besides the broader issues of misallocation and maldistribution of resources, is that dominant food companies are able to accumulate excessive material capabilities, which in turn can be used to fund costly corporate practices that have the potential to undermine public health efforts to improve population diet quality. Some of these corporate practices have non-market dimensions, e.g., lobbying, public relations, investing in scientific research and front groups, and donating to political candidates and campaigns, which serve to influence the interconnected policy, regulatory, institutional, ideological and broader socio-political structures that shape market environments [19]. Other corporate practices that are often funded, at least in part, by profits made from anticompetitive behaviour include a number of marketbased practices analysed in this paper. Notably, large food companies devote a substantial amount of 
resources to create and disseminate intense marketing and related communication strategies that fundamentally serve to maintain and increase consumer demand $[2,85$, 245]. As a case in point, the advertising budget of The Coca-Cola Company alone in 2019 (approximately USD 4.25 billion) was nearly the same as the entire 20182019 programme budget of the World Health Organization (approximately USD 4.42 billion) [246, 247]. In many cases, these marketing and communication practices are carefully designed to manipulate and distort consumer judgement [248]. Furthermore, dominant food companies have the ability to rapidly adapt their marketing and communication strategies to exploit events and dynamics that take place in the broader socio-political environment (e.g., Black Lives Matter movement, COVID-19 pandemic) [249-251].

A second important public health implication of the market power of dominant processed food manufacturers is that it increases their ability to directly shape retail food environments - in some cases via the use of anticompetitive practices, such as exclusive dealing arrangements and slotting fees. There is widespread recognition that unhealthy food environments, in which unhealthy food products are widely available and heavily promoted, are a major driver of unhealthy diets and obesity globally [5, 252]. Accordingly, where marketbased power imbalances favour companies that generate profits from the sale of unhealthy food and beverages, it is likely to negatively affect population diets and related health outcomes.

Third, the market power of dominant processed food manufacturers over small-scale producers can promote and reinforce the production of unhealthy processed food products, particularly in cases where the product portfolios of dominant manufacturers are mainly comprised of unhealthy food products. In order to remain economically viable, small-scale producers often have little choice but to produce commodity crops for dominant processed food manufacturers, instead of engaging in diverse crop production for healthier and more sustainable local food systems $[4,53]$.

There are also a number of manifestations of market power in which the public health implications are less clear. For example, the entry and penetration of 'healthier' substitute markets by dominant food companies, largely in response to consumer concerns and trends, could, on the surface, be perceived as beneficial for public health. The drive to differentiate and diversify products, for instance, based on issues of sustainability (e.g., shifting towards plant-based proteins) and health (e.g., promotion of fortified, functional and formulated food products) could lead to some public health benefits [18, $29,253]$. However, the public health community must remain vigilant in exploring whether these potential benefits are outweighed by more fundamental issues, such as how these strategies might lead to further consolidation of power in the hands of dominant food companies. Proponents of corporate technology-orientated solutions to improve population diet quality often contend that consolidated corporate power is not a concern in and of itself, given that powerful transnational firms are best placed to mobilise the necessary resources [4, 18, 53, 254]. Critics of this view, however, have pointed out that such a way of thinking is reductionist and could lead key policy makers to favour policy solutions that maintain the power of manufacturers of unhealthy foods at the expense of policy solutions that more comprehensively reform the healthiness of food systems $[4,53,156$, 254-256].

\section{External factors that shape (and are shaped by) market strategy}

Although the main context of analysis of this paper was the market environment, it is important to highlight that interconnected factors 'external' to the market environment - i.e. the broader economic, political-legal, sociocultural, demographic, technological, and ecological systems and processes - shape, and are shaped by, the market strategies of dominant food companies [21, 24, 257]. In this respect, market strategy analysis should not be a stand-alone inquiry, but instead serve to complement both non-market corporate strategy analyses and the examination of how underlying systemic processes, dynamics and paradigms (e.g. globalisation, liberalisation, financialisation) can facilitate and promote corporate interests over those of public health [6].

Market structures and market strategies are heavily shaped by underlying global and jurisdictional political economies. For instance, the market strategies of dominant food companies are influenced by trade and investment policy [116, 258, 259], competition policy [100], food and agricultural policy [113, 260], and fiscal and financial policy [261]. Such policies, laws, regulations and institutions vary significantly across jurisdictions. Market strategies, for instance, are less likely to be regulated in liberal market economies, in countries with weak regulatory institutional arrangements, or if they are transnational in nature and operate transboundary across and within states [262, 263]. Broader economic structures and processes also play a key role in shaping the market strategies of dominant food companies. For example, globalising economic processes, such as the integration of trade, investment, information and knowledge flows into global value chains, have enabled and promoted the emergence of enormous transnational food corporations $[29,80,116]$. Furthermore, the economic development that has occurred in many countries in recent decades has increased the purchasing power of a greater number 
of consumers, in turn boosting the sales growth of branded processed food products [2, 264]. Conversely, consumer confidence and the sales of branded processed food products have tended to drop during macroeconomic shocks, such as those associated with financial crises, which often lead to currency devaluation, increased unemployment and inflation [86, 265].

A range of socio-cultural and demographic drivers have facilitated population-level dietary shifts from freshly prepared meals to ready-to-consume, processed food products, notably urbanisation, the rise in paid employment for women and their engagement in less traditional gender-based roles, irregular working hours, a desire for cheap and convenient meals, reduced family size, and an increase in one-person households [91, 126, 170, 205]. Dominant food companies have also been able to harness ideas and values linked with modernisation and social desirability to aggressively market their branded food products, especially in emerging markets [91].

Market strategy is also shaped by technology-related innovations. Pertinent examples specific to dominant food companies include scientific developments in food processing and nutrition research (e.g. nanotechnology and biotechnology) [18, 108, 167, 209]; technological innovations in transportation and storage (e.g. just-in-time transportation technologies, cold chain technology) [132]; improvements in communication technology [91, 108]; Big Data platform technologies (especially with regard to targeted and integrated marketing) [201, 266]; and food production-related technological innovations, such as those that increase and standardise commodity production [33, 267].

\section{Policy implications and actions to address market-based power imbalances}

One of the goals of market strategy analysis of dominant food companies from a public health perspective is to identify policy actions that have the potential to address the market-based power imbalances that drive unhealthy diets. It is important to note that, while the focus of this paper is on policies designed to protect and promote public health, there are clear and important interconnections between public health goals and broader social and ecological goals.

Competition policy, at least in principle, plays an important role in regulating food supply chains by approaching and enforcing issues such as merger control, unfair trading practices, and vertical abuse of power [99, 153, 263]. Horizontal, vertical and cross-border merger control can prevent transactions that would further consolidate the market power of dominant food companies, as well as regulate their entry and penetration into emerging markets [63, 153, 263, 268, 269]. Additionally, the strengthened enforcement of unfair trading practices and vertical abuses, such as the use of slotting fees and 'category captaincy', could play an important role in promoting healthier food environments by reducing the ability of dominant food companies to control retail shelf space $[175,178,179]$.

However, it has often been argued that most competition policy regimes around the world have limited scope to promote healthier food systems [270, 271]. One fundamental reason for this is the narrow economic approach used to interpret consumer welfare in competition-related decision making. Notably, consumer price (and, to a lesser extent, availability and innovation) typically trumps broader social and ecological concerns, such as the healthfulness of food environments, in consumer welfare assessments $[269,271,272]$. This narrow economic approach to consumer welfare promotes the idea that cheap, widely available and unhealthy food products are beneficial, and not detrimental, to consumer welfare [272, 273].

One approach to reforming competition policy that has the potential to benefit public health could be to integrate the right to food, and in particular the right to adequate food, into the interpretation and application of competition policy [272-274]. Such an approach could ensure that competition authorities facing a choice between different interpretations of competition law involving dominant food companies (e.g., during assessments of proposed mergers) would be required to select the option that best protects and promotes public health whilst preserving the process of competition [273]. Similarly, broadening the scope of competition policy could help to counter industry group opposition to the implementation of certain public health policies, such as health-related taxes, on the grounds that they would distort competition [261, 272, 275-277]. There are important legal precedents in which the social benefits of implementing health-related taxes have been considered to outweigh the social costs of the potential distortion of competition. In 2018, for instance, the European Commission decided that the scope of the sugar-sweetened drinks tax implemented in Ireland was consistent with the health and nutrition objectives pursued by the government, and would not distort competition in an unduly manner [278].

Curbing the power of dominant food companies, as part of efforts to build healthier food supply chains, could also be partly achieved through policy action that supports food producers to participate in local and diversified food production, instead of being locked into commodity crop production. For instance, governments across different levels of governance could invest in infrastructure supporting local food supply chains for perishable products (e.g. improved transport and cold storage infrastructure); supporting farmers to engage in 
direct sales (e.g. participation in produce markets) and local processing and value-adding activities (e.g. food hubs); the upgrading of health, food quality and phytosanitary legislation to help small producers overcome existing restraints; increasing support for alternative food business models (e.g. food cooperatives); developing integrated agricultural knowledge and innovation systems that could help to address information asymmetries; and public procurement policies that mandate the procurement of healthy, local and sustainable food products $[269,279,280]$.

Policy actions that support vulnerable consumers overcome information-based power imbalances are also likely to play an important role in promoting healthy diets. For instance, countering exploitative marketing practices could be partly achieved via the prohibition of marketing, including digital marketing, of unhealthy foods to children, and the ban of unhealthy food marketing in school areas, on low shelves or checkout counters in supermarkets, and in TV programs scheduled at times when children typically watch TV. Packaging-related information asymmetries could also be partly overcome by establishing mandatory front-of-pack labelling schemes $[269,281,282]$. Finally, vulnerable consumers could be supported through policy actions that focus on health and diet quality equity. Such actions include those designed to improve the affordability and accessibility of healthy food alternatives, such as tax exemptions and subsidies on fresh produce and taxation of unhealthy products, urban policy that focuses on the distribution of healthy food options in deprived and vulnerable urban neighbourhoods, and greater access to fresh drinking water $[269,279,283]$.

\section{Contribution to the public health literature}

The typological framework presented in this paper is well-placed to inform a comprehensive examination of the market strategies and related practices used by dominant food companies within and across jurisdictions. Such studies will require the development of specific protocols to guide analyses. One example of a future research avenue could be to examine the market strategies used by a specific company, such as The Coca-Cola Company, across multiple countries over an extended period of time. Another potential research avenue could be to identify the aggregated market strategies used by the dominant market players of a specific food industry, such as sugar-sweetened beverages, within a specific jurisdiction. In both cases, research could include an examination of the use (or lack thereof) of remedies implemented by the relevant national competition authorities in response to the deployed market strategies.

More broadly, the presented market strategy framework can assist public health efforts to understand and address the ways in which corporate strategies influence health. To date, the majority of corporate strategy frameworks within the public health literature have largely focused on the non-market dimensions of strategies deployed by firms active in health-harming industries [ 9 , 284-287]. This emphasis on non-market strategy is well targeted, particularly in highly regulated industries such as tobacco, wherein firms have substantial incentives to secure favourable policy and regulatory environments to the detriment of public health [288]. Yet, firms in health-harming industries deploy both market and nonmarket strategies to consolidate power and maximise profits. Although a number of studies in the field of public health have, collectively, examined a variety of market strategies used by firms across a number of healthharming industries [245, 289-295], the approach to examine market strategies has not been systematic in the same way it has been for non-market strategies. In this respect, the presented typological framework could be used to complement existing political strategy analyses of dominant food companies [296-299], thereby broadening understanding of the wide range of corporate strategies used by dominant food companies that influence health and diet. Furthermore, this paper could serve as a blueprint for future public health research to systematically review the market strategies used by corporations in other food sectors (such as retail and food service), as well as corporations in other health-harming industries.

\section{Strengths and weaknesses of the study}

A key strength of this paper is that it is a systematic review covering a range of literature - notably public health, business, strategic management, and competition policy - that explores market strategy from a number of different perspectives. Furthermore, we used a novel approach to assess evidence quality and risk of bias. Another key strength of this paper is that it uses Porter's Five Forces framework to inform market strategy analysis, a framework that is very well-established throughout the business and strategic management literature and is well-placed to explore market-based power asymmetries. Although the use of Porter's Five Forces in the public health literature is not novel, to the best of our knowledge this is the first public health paper to use Porter's Five Forces framework to systematically analyse the use of market strategies used by corporation active in any health-harming industry or sector.

The paper has a number of important limitations. First, given the nature and subjectivity of interpreting power, there was an inevitable element of subjectivity in the way we framed different strategies according to the six strategic objectives. Second, there are clear interconnections and crossovers with a number of the strategies 
discussed, particularly in light of the difficulty in accurately delineating and defining food product markets and market segments. For example, there is a clear overlap between market segmentation, product differentiation and product diversification strategies, as well as the strategies linked with increasing consumer demand and building brand value. Third, it is important to note that certain sectors of the food industry may have unique market characteristics that cannot be generalised to the food manufacturing sector more broadly. For instance, breast milk substitute manufacturers may attempt to control distribution channels, such as health care and pharmaceutical channels, that are not generally used by firms active in other sectors of the food industry. Finally, this paper focused on dominant firms considered to primarily be processed food manufacturers. It is important to note that dominant companies from other functional levels have also integrated into the food manufacturing sector. The market dominance of actors in other sectors - such as powerful retailers (e.g., large supermarket chains), commodity traders (e.g., Archer Daniels Midland) and meat or dairy processors and wholesalers (e.g. WH Group, Fonterra) - can confer specific competitive advantages not covered in this paper. Given this limitation, a potential avenue for future research could be to look at the market-based power asymmetries specific to the different functional levels of the food value chain.

\section{Conclusion}

This paper has presented a novel typological market strategy framework specific to dominant food companies and their use and consolidation of market power vis-àvis other market-based actors. Informed by Porter's Five Forces framework, the presented framework outlines key market strategies and related practices in relation to six key strategic objectives. The presented framework is well-placed to inform analysis of market strategies used by dominant food companies as part of public health efforts to understand and address the ways in which the use of corporate strategies by dominant food companies can undermine public health and diet quality. In addition, the presented market strategy framework is well-placed to identify leverage points within a specific jurisdiction that could be targeted by policy actions to address market-based power imbalances. Notably, competition policies related to merger control and the misuse of market power have the potential to create healthier food systems. Given that in many cases competition authorities fail to incorporate the necessary range of social and ecological considerations that concern societal welfare, the public health community should aim to position itself as an important driver of competition policy reform that truly takes consumer welfare and public interest considerations into account.

\section{Supplementary Information}

The online version contains supplementary material available at https://doi. org/10.1186/s12992-021-00667-7.

Additional file 1.

Additional file 2.

Acknowledgements

Not applicable.

Authors' contributions

OW conceived the original research idea. BW and GS developed the study design. BW collected, analysed and interpreted the data. BW wrote the draft manuscript. GS, OW and VN verified, reviewed and edited the generated findings and draft manuscript. The author(s) read and approved the final manuscript.

Funding

No sources of funding to declare.

Availability of data and materials

All data generated or analysed during this study are included in this published article [and its supplementary information files].

Ethics approval and consent to participate

Not applicable.

Consent for publication

Not applicable.

Competing interests

The authors declare that they have no competing interests.

\section{Author details}

${ }^{1}$ Global Obesity Centre, Deakin University, Melbourne, Australia. ${ }^{2}$ School of Political Science and International Studies, University of Leeds, Leeds, UK.

${ }^{3}$ Macquarie Law School, Macquarie University, Sydney, Australia.

Received: 16 November 2020 Accepted: 18 January 2021

Published online: 26 January 2021

References

1. Afshin A, Sur PJ, Fay KA, Cornaby L, Ferrara G, Salama JS, et al. Health effects of dietary risks in 195 countries, 1990-2017: a systematic analysis for the global burden of disease study 2017. Lancet. 2019;393:1958-72. https://doi. org/10.1016/s0140-6736(19)30041-8.

2. Moodie R, Stuckler D, Monteiro C, Sheron N, Neal B, Thamarangsi T, et al. Profits and pandemics: prevention of harmful effects of tobacco, alcohol, and ultra-processed food and drink industries. Lancet. 2013;381:670-9. https://doi.org/10.1016/s0140-6736(12)62089-3.

3. Stuckler D, Nestle M. Big food, food systems, and global health. PLoS Med. 2012;9:e1001242. https://doi.org/10.1371/journal.pmed.1001242.

4. IPES-Food. Unravelling the Food-Health Nexus: Addressing practices, political economy, and power relations to build healthier food systems. The Global Alliance for the Future of Food and IPES-Food, 2017.

5. Swinburn BA, Kraak VI, Allender S, Atkins VJ, Baker PI, Bogard JR, et al. The global Syndemic of obesity, Undernutrition, and climate change: the lancet commission report. Lancet. 2019;393:791-846. https://doi.org/10.1016/s01406736(18)32822-8.

6. Mialon M. An overview of the commercial determinants of health. Glob Health. 2020;16:74. https://doi.org/10.1186/s12992-020-00607-x.

7. Martinez Steele E, Baraldi LG, Louzada ML, Moubarac JC, Mozaffarian D, Monteiro CA. Ultra-processed foods and added sugars in the US diet: evidence from a nationally representative cross-sectional study. BMJ Open. 2016;6:e009892. https://doi.org/10.1136/bmjopen-2015-009892.

8. Malik VS, Popkin BM, Bray GA, Despres JP, Hu FB. Sugar-sweetened beverages, obesity, type 2 diabetes mellitus, and cardiovascular disease risk. Circulation. 2010;121:1356-64. https://doi.org/10.1161/CIRCULATIONAHA.109. 876185. 
9. Mialon M, Swinburn B, Sacks G. A proposed approach to systematically identify and monitor the corporate political activity of the food industry with respect to public health using publicly available information. Obes Rev. 2015;16:519-30. https://doi.org/10.1111/obr.12289.

10. Zimmerman FJ. Using marketing muscle to sell fat: the rise of obesity in the modern economy. Annu Rev Public Health. 2011;32:285-306. https://doi. org/10.1146/annurev-publhealth-090810-182502.

11. Europe WHO. Tackling food marketing to children in a digital world: transdiscplinary perspectives. Copenhagen, Denmark: World Health Organization; 2016.

12. Franz C, Kickbusch I. The capital-NCD-nexus: the commercial determinants of health and global capital flows. Eurohealth. 2018;24:21-4.

13. Adjoian T, Dannefer R, Farley SM. Density of outdoor advertising of consumable products in NYC by neighborhood poverty level. BMC Public Health. 2019;19:1479. https://doi.org/10.1186/s12889-019-7821-y.

14. Jackson M, Harrison P, Swinburn B, Lawrence M. Unhealthy food, integrated marketing communication and power: a critical analysis. Crit Public Health. 2014;24:489-505. https://doi.org/10.1080/09581596.2013.878454.

15. Mehta K, Phillips C, Ward P, Coveney J, Handsley E, Carter P. Marketing foods to children through product packaging: prolific, unhealthy and misleading. Public Health Nutr. 2012;15:1763-70. https://doi.org/10.1017/ S1368980012001231.

16. Story M, French S. Food advertising and marketing directed at children and adolescents in the US. Int J Behav Nutr Phys Act. 2004;1.

17. Lawrence M, Rayner M. Functional foods and health claims: a public health policy perspective. Public Health Nutr. 1998;1:75-82. https://doi.org/10.1079/ phn19980013.

18. Scrinis G. Reformulation, fortification and functionalization: big food corporations' nutritional engineering and marketing strategies. J Peasant Stud. 2015:43:17-37. https://doi.org/10.1080/03066150.2015.1101455.

19. Baron D. Integrated Strategy: market and nonmarket components. Calif Manag Rev. 1995;37:47-65.

20. Levy D, Egan D. A neo-Gramscian approach to corporate political activity: conflict and accommodation in the climate change negotiations. J Manag Stud. 2003;40

21. Porter ME. The five competitive forces that shape Strategy. Harv Bus Rev. 2008:23-41.

22. Porter ME. Competitive strategy: techniques for analyzing industries and companies. New York: Free Press; 1980.

23. Barney JB, Mackey A. Monopoly profits, efficiency profits, and teaching strategic management. Academy of Management Learning \& Education. 2018;17:359-73. https://doi.org/10.5465/amle.2017.0171.

24. Sammut-Bonnici T, Galea D. PEST analysis. In: Cooper PSCL, editor. Wiley encyclopedia of. Management: John Wiley \& Sons, Ltd.; 2014.

25. Herrick C. Shifting blame/selling health: corporate social responsibility in the age of obesity. Sociol Health IIIn. 2009;31:51-65. https://doi.org/10.1111/j. 1467-9566.2008.01121.x.

26. Foucault M. The subject and power. Chicago Journals: Critical Inquiry. 1982; 8:777-95.

27. International Competition Network. Market Definition 2018 [5 February 2020]. Available from: https://www.internationalcompetitionnetwork.org/ training/market-definition/.

28. Brownell K, Warner K. The perils of ignoring history: big tobacco played dirty and millions died. How similar is big food? The Millbank Quarterly. 2009:87:259-94

29. IPES-Food. Too big to feed: Exploring the impacts of mega-mergers, concentration, concentration of power in the agri-food sector. 2017

30. Hawkes $C$. Identifying innovative interventions to promote healthy eating using consumption-oriented food supply chain analysis. J Hunger Environ Nutr. 2009;4:336-56. https://doi.org/10.1080/19320240903321243.

31. Passport. World Market for Packaged Food. Euromonitor International, 2020.

32. Passport. World Market for Soft Drinks. Euromonitor International, 2020.

33. Sexton RJ. Market power, misconceptions, and modern agricultural markets. Am J Agric Econ. 2012;95:209-19. https://doi.org/10.1093/ajae/aas102.

34. Monteiro C, Cannon G, Lawrence M, da Costa LM, Machado P. Ultra-processed foods, diet quality, and health using the NOVA classification system. Food and Agriculture Organization of the United Nations: Rome; 2019.

35. Moubarac J-C, Parra DC, Cannon G, Monteiro C. Food classification systems based on food Processing: significance and implications for policies and actions: a systematic literature review and assessment. Curr Obes Rep. 2014; 3:256-72.
36. Baker P, Machado P, Santos T, Sievert K, Backholer K, Hadjikakou M, et al. Ultra-processed foods and the nutrition transition: global, regional and national trends, food systems transformations and political economy drivers. Obes Rev. 2020. https://doi.org/10.1111/obr.13126.

37. Monteiro C, Cannon G, Lawrence M, da Costa LM, Machada PP. Ultraprocessed foods, diet quality, and health using the NOVA classification system. Food and Agriculture Organization of the United Nations: Rome; 2019

38. Monteiro CA, Cannon G, Moubarac JC, Levy RB, Louzada MLC, Jaime PC. The UN decade of nutrition, the NOVA food classification and the trouble with ultra-processing. Public Health Nutr. 2018;21:5-17. https://doi.org/10. 1017/S1368980017000234

39. Louzada M, Ricardo CZ, Steele EM, Levy RB, Cannon G, Monteiro CA. The share of ultra-processed foods determines the overall nutritional quality of diets in Brazil. Public Health Nutr. 2018;21:94-102. https://doi.org/10.1017/ S1368980017001434

40. Machado PP, Steele EM, Levy RB, Sui Z, Rangan A, Woods J, et al. Ultraprocessed foods and recommended intake levels of nutrients linked to noncommunicable diseases in Australia: evidence from a nationally representative cross-sectional study. BMJ Open. 2019;9:e029544. https://doi. org/10.1136/bmjopen-2019-029544.

41. Rauber F, da Costa Louzada ML, Steele EM, Millett C, Monteiro CA, Levy RB. Ultra-processed food consumption and chronic non-communicable diseases-related dietary nutrient profile in the UK (2008(-)2014). Nutrients. 2018;10. https://doi.org/10.3390/nu10050587.

42. Rico-Campà A, Martínez-González MA, Alvarez-Alvarez I, Mendonça RdD, de la Fuente-Arrillaga C, Gómez-Donoso C, et al. Association between consumption of ultra-processed foods and all cause mortality: SUN prospective cohort study. Bmj. 2019. doi: https://doi.org/10.1136/bmj.l1949.

43. Blanco-Rojo R, Sandoval-Insausti H, Lopez-Garcia E, Graciani A, Ordovas JM, Banegas JR, et al. Consumption of ultra-processed foods and mortality: a National Prospective Cohort in Spain. Mayo Clin Proc. 2019;94:2178-88. https://doi.org/10.1016/j.mayocp.2019.03.035.

44. Nardocci M, Leclerc BS, Louzada ML, Monteiro CA, Batal M, Moubarac JC. Consumption of ultra-processed foods and obesity in Canada. Can J Public Health. 2019;110:4-14. doi: https://doi.org/10.17269/s41997-018-0130-x.

45. Canhada SL, Luft VC, Giatti L, Duncan BB, Chor D, Fonseca M, et al. Ultraprocessed foods, incident overweight and obesity, and longitudinal changes in weight and waist circumference: the Brazilian longitudinal study of adult health (ELSA-Brasil). Public Health Nutr. 2020;23:1076-86. https://doi. org/10.1017/S1368980019002854.

46. Srour B, Fezeu LK, Kesse-Guyot E, Allès B, Méjean C, Andrianasolo RM, et al. Ultra-processed food intake and risk of cardiovascular disease: prospective cohort study (NutriNet-Santé). BMJ. 2019. https://doi.org/10.1136/bmj.I1451.

47. Srour B, Fezeu LK, Kesse-Guyot E, Alles B, Debras C, Druesne-Pecollo N, et al. Ultraprocessed food consumption and risk of type 2 diabetes among participants of the NutriNet-Sante prospective cohort. JAMA Intern Med. 2019. https://doi.org/10.1001/jamainternmed.2019.5942.

48. Martinez Steele E, Juul F, Neri D, Rauber F, Monteiro CA. Dietary share of ultra-processed foods and metabolic syndrome in the US adult population. Prev Med. 2019;125:40-8. https://doi.org/10.1016/j.ypmed.2019.05.004.

49. Fiolet T, Srour B, Sellem L, Kesse-Guyot E, Alles B, Mejean C, et al. Consumption of ultra-processed foods and cancer risk: results from NutriNet-Sante prospective cohort. BMJ. 2018;360:k322. https://doi.org/10. 1136/bmj.k322.

50. Melo B, Rezende L, Machado P, Gouveia N, Levy R. Associations of ultraprocessed food and drink products with asthma and wheezing among Brazilian adolescents. Pediatr Allergy Immunol. 2018;29:504-11. https://doi. org/10.1111/pai.12911.

51. Julia C, Martinez L, Alles B, Touvier M, Hercberg S, Mejean C, et al. Contribution of ultra-processed foods in the diet of adults from the French NutriNet-Sante study. Public Health Nutr. 2018;21:27-37. https://doi.org/10. 1017/S1368980017001367.

52. Gómez-Donoso C, Sánchez-Villegas A, Martínez-González MA, Gea A, de Deus MR, Lahortiga-Ramos F, et al. Ultra-processed food consumption and the incidence of depression in a Mediterranean cohort: the SUN project. Eur J Nutr. 2020;59:1093-103.

53. IPES-Food. From uniformity to diversity: a paradigm shift from industrial agriculture to diversified agroecological systems. International Panel of Experts on Sustainable Food Systems, 2016.

54. Stuckler D, McKee M, Ebrahim S, Basu S. Manufacturing epidemics: the role of global producers in increased consumption of unhealthy commodities 
including processed foods, alcohol, and tobacco. PLoS Med. 2012;9: e1001235. https://doi.org/10.1371/journal.pmed.1001235.

55. Moher D, Liberati A, Tetzlaff J, Altman DG, Group P. Preferred reporting items for systematic reviews and meta-analyses: the PRISMA statement. BMJ. 2009;339:b2535. https://doi.org/10.1136/bmj.b2535.

56. Higgins J, Green S. Cochrane handbook for systematic reviews of interventions. Wiley-Blackwell: Chichester; 2008.

57. Rogers R, Caswell J. Strategic management and the internal Organization of Food Marketing Firms. Agribusiness. 1988:4:3-10.

58. Moss D, Taylor R. Short ends of the stick: the plight of growers and consumers in concentrated agricultural supply chains. Wis Law Rev. 2014.

59. EUR-LeX. COMMISSION DECISION of 08/08/2001 declaring a concentration to be compatible with the common market (Case No IV/M.2399 - FRIESLAN D COBERCO/NUTRICIA) according to Council Regulation (EEC) No 4064/89. EUR-Lex. 2001.

60. EUR-Lex. Commission Decision of 22 July 1992 relating to a proceeding under Council Regulation (EEC) No 4064/89 (Case No IV/M.190 - Nestlé/ Perrier). EUR-Lex. 2002.

61. Regulatory News Service. Unilever PLC Final Results. RNS. 2009.

62. EUR-Lex. Summary of Commission Decision of 17 December 2008 declaring a concentration compatible with the common market and the functioning of the EEA Agreement (Case COMP/M.5046 — Friesland Foods/Campina). European Communities, 2008 Contract No.: C(2008) 8459.

63. OECD Competition Committee. Competition Issues in the Food Chain Industry. OECD, , 2014 Contract No.: DAF/COMP(2014)16.

64. United States Department of Agriculture. New Directions in Global Food Markets. USDA, 2005 Contract No.: Agriculture Information Bulletin Number 794.

65. EUR-Lex. Commission Decision of 04/10/2013 declaring a concentration to be compatible with the common market (Case No COMP/M.6924 - REFR ESCO GROUP / PRIDE FOODS) according to Council Regulation (EC) No 139/ 2004. EUR-Lex. 2014.

66. EUR-Lex. Commission Decision of 28/05/2013 declaring a concentration to be compatible with the common market (Case No COMP/M.6813 - MCCAIN FOODS GROUP / LUTOSA BUSINESS) according to Council Regulation (EC) No 139/2004. EUR-Lex. 2013.

67. EUR-Lex. Commission Decision of 11/05/2012 declaring a concentration to be compatible with the common market (Case No COMP/M.6522 - GROUPE LACTALIS / SKANEMEJERIER) according to Council Regulation (EC) No 139/ 2004. EUR-Lex. 2012.

68. EUR-Lex. Commission Decision of 25/06/2002 declaring a concentration to be compatible with the common market (Case No COMP/M.2817 - BARILLA / BPL / KAMPS) according to Council Regulation (EEC) No 4064/89. EUR-Lex. 2002.

69. EUR-Lex. COMMISSION DECISION of 16/10/2000 declaring a concentration to be compatible with the common market (Case No IV/M.2072 - PHILLIP MORRIS/NABISCO) according to Council Regulation (EEC) No 4064/89. EURLex. 2000

70. Federal Register. United States v. Grupo Bimbo S.A.B. de C.V., et al.; Proposed Final Judgment and Competitive Impact Statement. FREG. 2011; 76.

71. Legazkue IP. Business investment Strategy and technological innovation in agribusiness firms: Purdue University; 1999

72. Lopez T. San Miguel's market power. Manila Standard Today. 2017.

73. Times F. Barry Callebaut. Financial Times. 2014.

74. De Jonquieres $G$, Dawkins W. An appetite for acquisitions: Europe's market in food is being transformed by rpedators and fiercer competition. Financial Times. 1992.

75. Khoo L. Competition watchdog clears JDE's proposed acquisition of OldTown Singapore: the straits Times; 2018 [22 July 2020]. Available from: https://www.straitstimes.com/business/companies-markets/competitionwatchdog-clears-jdes-proposed-acquisition-of-oldtown.

76. Antitrust Division. United States V. Danone S.A. and the WhiteWave Foods Company; Proposed Final Judgment and Competitive Impact Statement U. S. District Court for the District of Columbia: Federal Register; 2017 [22 July 2020]. Available from: https://www.federalregister.gov/documents/2017/04/1 9/2017-07924/united-states-v-danone-sa-and-the-whitewave-foodscompany-proposed-final-judgment-and-competitive.

77. Henderson R. Merger allowed despite porridge-market fears. The Herald. 2015.

78. R\&l View. Two Coca-Cola Bottlers to Discuss Integration. R\&l View. 2016.
79. Business Monitor International. NourishCo Harnessing India's Functional Beverage Potential. Business Monitor International, 2012.

80. Clapp J. The rise of mega-companies in the global food system: implications for economic and environmental sustainability. In: Agrologists Alo, editor. AlA conference on agriculture, Food and the Environment. Banff, Canada2019.

81. Passport. Competitor Strategies in Packaged Food. Euromonitor International, 2020.

82. Stichele MV, van der Wal S. The profit behind your plate: critical issues in the processed food Industry. Amsterdam, The Netherlands: SOMO - Centre for Research on Multinational Corporations; 2006.

83. Baker P, Friel S. Food systems transformations, ultra-processed food markets and the nutrition transition in Asia. Glob Health. 2016;12:80. https://doi.org/ 10.1186/s12992-016-0223-3.

84. Lee E. The World Health Organization's global Strategy on diet, physical activity, and health: turning Strategy into action. Food \& Drug Law Journal. 2005;60:569-602.

85. Monteiro CA, Cannon G. The impact of transnational "big food" companies on the south: a view from Brazil. PLoS Med. 2012;9:e1001252. https://doi. org/10.1371/journal.pmed.1001252.

86. Industry C. Volatility hits retail market downunder. Candy Industry. 1998

87. Solutions F. Nigeria: food \& drink report Q2 2019. Fitch Solutions Group Limited: UK: 2019

88. Mitchell S. Coca-Cola Amatil reviews value of Indonesia after the Coca-Cola Co write down. Financ Rev. 2018.

89. Buckley N. Lucas L. Financial Times: PepsiCo to buy Russia's Wimm-BillDann; 2010.

90. Post B. Noodle manufacturers seek to expand their markets. Bangkok Post. 2001.

91. Black E. Globalization of the Food Industry: Transnational Food Corporations, the Spread of Processed Food, and Their Implications for Food Security and Nutrition. In: Institute SG, editor. Indepedent Study Project (ISP) Collection2016.

92. Passport. Innovation in Meals: Asia Pacific Through a Global Lens. Euromonitor International, 2020.

93. Feunteun T. Cartels and the right to food: an analysis of States' duties and options. J Int Econ Law. 2015;18:341-82. https://doi.org/10.1093/jiel/jgv019.

94. Corp Couns Quarterly. Quarterly Updates. California, US: Corporate Counsel's Quarterly; 2016

95. Bonnet C, Boumara-Mechemache Z. Empirical methodology for the evaluation of collusive behaviour in vertically-related markets: an application to the "yoghurt cartel" in France. International Review of Law \& Economics. 2020;61.

96. Levenstein M, Marvão C, Suslow V. Preventing cartel recidivism. Antitrust. 2016;30.

97. Bhuyan S, Lopez RA. Oligopoly power in the food and tobacco industries. Am J Agric Econ. 1997;79:1035-43.

98. Fine proceedings against confectionery manufacturers. Bundeskartellamt; 2013.

99. European Competition Network. ECN Activities in the Food Sector: Report on competition law enforcement and market monitoring activities by European competition authorities in the food sector. ECN, 2012.

100. Antonielli M, Mariniello M. Antitrust risk in EU manufacturing: a sector-level ranking. Bruegel, 2014

101. Connor JM. The changing structure of global food markets: dimensions, effects, and policy implications. In: Department of Agricultural Economics PU, editor. West Lafayette, Indiana2003.

102. Best D. Dairy companies to appeal latest Spain collusion ruling: just food; 2019 [22 July 2020]. Available from: https://www.just-food.com/news/dairycompanies-to-appeal-latest-spain-collusion-ruling_id141859.aspx.

103. Strauss M. Documents reveal Canada bread, Weston as key players in breadprice-fixing scheme: the globe and mail; 2018 [22 July 2020]. Available from: https://www.theglobeandmail.com/report-on-business/canada-breadweston-bakeries-and-major-grocers-behind-alleged-bread-price-fixingcompetition-bureau/article37802794/.

104. Jargon J. Corporate News: retailers' lawsuits accuse candy makers of fixing prices. Wall Street J. 2008.

105. Southey F Canned vegetable cartel: whistle-blower Bonduelle avoid ca 250m euro fine in anti-trust ruling Crwaley, UK: William Reed Business Media Ltd 2019 [10 August 2020]. Available from: https://www. foodnavigator.com/Article/2019/10/02/Bonduelle-granted-immunity-incanned-vegetable-cartel-scandal. 
106. Haucap J, Heimeshoff U, Schultz LM. Legal and Illegal Cartels in Germany between 1958 and 2004. In: (DICE) DIfCE, editor. DICE Discussion Paper. Düsseldorf2010.

107. Brandow GE. Market power and its sources in the food Industry. Am J Agric Econ. 1969:51:1-12.

108. Jones E, Mercier S. The power of biotechnology to impel change in the grain and oilseeds markets. Willamette Journal of International Law and Dispute Resolution. 2004;12.

109. Citi GPS. Feeding the future: how innovation and shifting consumer preferences can help feed a growing planet. Global Perspectives \& Solutions: Citi GPS; 2018

110. The Associated Press. Company News; Heinz Buys 19.5\% Stake in Hain Food for \$100 Million. The New York Times. 1999;Sect. Company News.

111. Euromonitor International. Mondelez Ireland production Itd in packaged food (Ireland). Euromonitor International Ltd, 2017.

112. Euromonitor International. Nestlé Italiana SpA in packaged food (Italy). Euromonitor International Ltd, 2017.

113. Business Monitor International. PepsiCo global company Strategy. BMl Research: A Fitch Group Company; 2017.

114. Smith B. Are new alliances indicative of joint venture activity for food and beverage Industry? Food Processing. 2012 [11 August 2020]; Available from: https://www.foodprocessing.com/articles/2012/power-lunch-brian-smith/.

115. Ridler J. Premier Foods' sales boosted by 'strategic' partnerships: William Reed Business Media; 2017 [14 August 2020]. Available from: https://www. foodmanufacture.co.uk/Article/2017/11/15/Food-manufacturer-boosts-salesthrough-partnerships\#: :text=Premier\%20Foods\%20reported\%20sales\%2 Oand,with\%20Nissin\%20and\%20Mondel\%C4\%93z\%20International.\&text= Branded\%20sales\%20grew\%20by\%200.9,7.4\%25\%20to\%20\%C2A340.3M.

116. Hawkes C. Uneven dietary development: linking the policies and processes of globalization with the nutrition transition, obesity and diet-related chronic diseases. Glob Health. 2006;2:4. https://doi.org/10.1186/1744-8603-2-4.

117. Agos F. Consumption slides in Asia. Candy Industry. 1998;33.

118. Arnotts Ltd v Trade Practices Commission. Lockhart, Wilcox Gummow, JJ: Federal Court of Australia; 1990.

119. Salvo A. Cut-throat fringe competition in an emerging country market: tax evasion or the absence of market power? J Ind Econ. 2009;57:677-711.

120. Wooster AK. Primary-Line Price Discrimination under S2(a) of the Clayton Act, as Amended by the Robinson-Patman Price Discrimination Act (15 U.S. C.A. S 13(a)). American Law Reports. 2001;581.

121. Eizenberg A, Salvo A. The rise of fringe competitors in the wake of an emerging middle class: an empirical analysis. Am Econ J Appl Econ. 2015;7:85-122.

122. HJ Heinz Company v. Beech-nut life savers, Inc. Levet, District Judge: United States District Court S.D. New York; 1960.

123. Committee OC. Predatory Foreclosure. OECD 2004 Contract No.: DAF/ $\operatorname{COMP}(2005) 14$.

124. Wolburg JM. Double-Cola and antitrust issues: staying alive in the soft drink wars. J Consum Aff. 2003:37.

125. CTK Business News. Imported baby food likely to be submitted to extra duties. CTK. 1998.

126. Moubarac JC, Batal M, Martins AP, Claro R, Levy RB, Cannon G, et al. Processed and ultra-processed food products: consumption trends in Canada from 1938 to 2011. Can J Diet Pract Res. 2014;75:15-21. https://doi. org/10.3148/75.1.2014.15

127. Gómez MI, Schiefer G, Rao VR. Market power and trade promotions in US supermarkets. Br Food J. 2009;111:866-77. https://doi.org/10.1108/ 00070700910980973

128. FAO. Globalization of food systems in developing countries: impact on food security and nutrition. Rome: Food and Agriculture Organization of the United Nations; 2004.

129. Monteiro CA, Moubarac JC, Cannon G, Ng SW, Popkin B. Ultra-processed products are becoming dominant in the global food system. Obes Rev. 2013;14(Suppl 2):21-8. https://doi.org/10.1111/obr.12107.

130. Shoebridge N. In the chocolate wars, there is still life in Mars; 1997.

131. EU B. Premier foods: power brands growth momentum continues. 2013.

132. Murphy S. Concentrated market power and agricultural trade. Ecofair Trade Dialogue, 2006

133. Toomey $D$. The influence of product placement on pre-teen decision making. Anderson, Indiana: Anderson University; 2011.

134. Endres AB. United States food law update: Labelling controversies, biotechnology litigation, and the safety of imported food. Journal of Food Law \& Policy. 2007;3
135. Monteiro C, Gomes F, Cannon G. The snack attack. Am J Public Health. 2010;100:975-81.

136. Scott A. Sampling smarts: brands tap into the $\$ 768$ billion purchasing power of Hispanics. Marketers. 2006.

137. Parmar A. Dependent variables: sound global strategies rely on certain factors. Marketing News. 2002

138. Weber J, Picciola M. Hunger games: battling for food and Industry supremacy in the hourglass economy. Food Logistics. 2012;56.

139. Moreno J. Mexican food supplier cashes in on U.S. Hispanics. Houston Chronicle. 2007

140. Subramanian S. Is fair trade finished? The Guardian: Fairtrade changed the way we shop. But major companies have started to abandon it and set up their own in-house imitations - threatening the very idea of fair trade; 2019.

141. Hyvönen S. Competitive advantage, bargaining power, and organizational performance: the case of Finnish food manufacturing firms. Agribusiness. 1995; 11:333-48

142. Raciti R. The terminology wars: the dairy Pride act and its potential impingement on innovation. Ohio State Business Law Journal. 2020;14.

143. Venturini $L$. Vertical competition between manufacturers and retailers and upstream incentives to innovate and differentiate. In: Cuore UCdS, editor. Marketing dynamics within the global trading system: new perspectives. Milan, Italy2006

144. Frean A. Ruthless dealmakers are always full of beans - Warren Buffett and Jorge Lemann run an empire with an endless appetite for top brands. The Times. 2017

145. Westfield M. Under attack - how big brands are being hammered by retail giants. The Weekend Australian. 2002.

146. CCS. CCS's Findings From the Market Inquiry into the Supply of Formula Milk Singapore: Competition \& Consumer Commission; 2017 [22 July 2020]. Available from: https://www.cccs.gov.sg/media-and-consultation/newsroom/ media-releases/formula-milk-market-inquiry-findings.

147. Yeoh YH. Industry report C1211A: soft drink manufacturing in Australia. IBISWorld. 2019

148. Vuong B. Industry report C1182: chocolate and confectionery manufacturing in Australia. IBISWorld, 2019.

149. Vuong B. Industry report C1191: snack food manufacturing in Australia. IBISWorld, 2019.

150. Reeves M. Industry report C1132: ice cream manufacturing in Australia. IBISWorld, 2019.

151. Hendrickson M, Wilkinson J, Heffernan WD, Gronski R. The global food system and nodes of power. SSRN Electron J. 2008. https://doi.org/10.2139/ ssrn.1337273.

152. Pritchard B. The tangible and intangible spaces of agro-food capital. In: Sydney Uo, editor. International rural sociology association world congress $X$, Rio de Janeiro, Brazil2000.

153. Warren K. Vertical integration and competition policy. Bus Strateg Rev. 1992 $33-55$.

154. Scrinis G. Big Food corporations and the nutritional marketing and regulation of processed foods. Canadian Food Studies / La Revue canadienne des études sur l'alimentation. 2015;2. doi: 10.15353/cfs-rcea.v2i2.113.

155. Henson S, Reardon T. Private Agri-food standards: implications for food policy and the Agri-food system. Food Policy. 2005;30:241-53. https://doi. org/10.1016/j.foodpol.2005.05.002.

156. Clapp J, Scrinis G. Big food, Nutritionism, and corporate power. Globalizations. 2016:14:578-95. https://doi.org/10.1080/14747731.2016. 1239806.

157. Private Label Buyer. As Ice Cream Goes, So Goes Private Label. PLB. 2010.

158. Arnold J. Optimizing Food Processors' Supply Chain Strategies: Halcyon Business Publications Inc.; 2016 [11 August 2020]. Available from: https:// www.areadevelopment.com/FoodProcessing/Q4-2016-food-processingguide/Optimizing-food-processors-supply-chain-strategies-453311.shtml.

159. Passport. Functional Food and Growing Importance of Labelling. Euromonitor International, 2020.

160. Passport. Innovation in Non-alcoholic Drinks: 3 Innovation Platforms in Soft Drinks. Euromonitor International, 2020

161. Herath D. Impediments to the ability of Canadian food-Processing firms to compete: evidence from a survey on innovation. Agribusiness. 2014;30:24464. https://doi.org/10.1002/agr.21361.

162. Pritchard B. The transnational corporate networks of breakfast cereals in Asia. Environment and Planning A: Economy and Space. 2000;32:789-804. https://doi.org/10.1068/a32113. 
163. Carraresi L, Mamaqi X, Albisu L, Banterle A. Strategic capabilities and performance: an application of resource-based view in Italian food SMEs. Networks IEFoSDaliF, editor: In; 2012.

164. Euromonitor International. Innocent drinks Co Itd in soft drinks (Ireland): Euromonitor International Ltd.; 2017.

165. Co C-C. v. Busch F.Supp. 405 (E.D. Pa. 1942). U.S. District Court for the Eastern District of Pennsylvania: Ganey, District Judge; 1942.

166. Newswire P. Mother parkers tea \& coffee champions independent singleserve coffee. PRN. 2014.

167. ETC Group. Down on the farm: the impact of Nano-scale technologies on food and agriculture. ETC Group: Ottawa, Canada; 2004.

168. Stott M. Exploiting intellectual property rights in the UK's food and drink sector: AgFunder News; 2019 [14 August 2020]. Available from: https:// agfundernews.com/exploiting-intellectual-property-rights-in-the-uks-foodand-drink-sector.html.

169. PatSnap. Intellectual property \& food (patents vs trade secrets): PatSnap; 2017 [14 August 2020]. Available from: https://www.patsnap.com/resources/ blog/intellectual-property-food-patents-vs-trade-secrets/\#: :text=Unlike\%2 Opatents\%2C\%20there\%20is\%20no,are\%20much\%20harder\%20to\%20obtain.

170. Churchill D. Soft drinks bubble risks bursting: the background to the industry's MMC referral. Financial Times. 1990.

171. Buhr B. Economics of antitrust in an era of global Agri-food supply chains: litigate, legislate and/or facilitate? Drake Journal of Agricultural Law. 2010;15.

172. Pritchard B. Geographies of the firm and transnational agro-food corporations in East Asia. Singap J Trop Geogr. 2000;21:246-62.

173. Sikka $P$, Willmott $H$. The dark side of transfer pricing: its role in tax avoidance and wealth relativeness. In: Centre for Global Accountability UoE, editor. Essex, UK2010.

174. Zenger $\mathrm{H}$. Loyalty rebates and the competitive process. J Compet Law Econ. 2012;8:717-68. https://doi.org/10.1093/joclec/nhs023.

175. Klein B, Wright J. The economics of slotting contracts. J Law Econ. 2007;50: 421-54

176. Tharp J. Raising rivals' costs: of bottlenecks, wine, and bottled soda. Northwest Univ Law Rev. 1989:84.

177. Genchev B, Mortimer JH. Empirical evidence on conditional pricing practices: a review. Antitrust Law Journal. 2017:81.

178. Carameli LS Jr. The anti-competitive effects and antitrust implications of category management and category captains of consumer products. Chicago-Kent Law Review. 2004;79.

179. Jennings MM, Aalberts RJ, Happel SK. The economics, ethics and legalities of slotting fees and other allowances in retail markets. Journal of Law and Commerce. 2001;21

180. Frito-Lay, Inc., Plaintiff V. The Bachman Co., Defendant; The Bachman Co., Counterclaimant V. Frito-Lay, Inc., Counterdefendant. U.S. District Court, S.D. New York; 1986.

181. European Commission. Competition: commission makes commitments from Coca-Cola legally binding, increasing consumer choice Brussels: European Commission 2005 [9 July 2020]. Available from: https://ec.europa.eu/ commission/presscorner/detail/en/IP 05 775.

182. Hingley MK. Power imbalance in UK Agri-food supply channels: learning to live with the supermarkets? J Mark Manag. 2005;21:63-88. https://doi.org/10. $1362 / 0267257053166758$

183. Quinn I. Adjudicator rules payment for shelf space is beyond remit: the grocer; 2017 [10 Jul 2020]. Available from: https://www.thegrocer.co.uk/ supermarkets/adjudicator-rules-payment-for-shelf-space-is-beyond-remit/54 8207.article.

184. Alan K. Clemmy's v. Nestle anti-trust case not melting away: Public Reconrd; 2014

185. Kanter J. EU puts consumers choice first when regulating competition. Wall Street J. 2005

186. News DJB. Cadbury files suit against PepsiCo alleging violation of antitrust Laws. DJON. 2001

187. Hildred W, Pinto J. Impacts of supply chain management on competition. In: Administration CoB, editor. Working paper series 02-10. Norther Arizona University, Flagstaff, Arizona2002.

188. Hays C. How Coke Pushed Rivals Off the Shelf. The New York Times. 2000; Sect. 3.

189. Touboulic A, Chicksand D, Walker H. Managing imbalanced supply chain relationships for sustainability: a power perspective. Decis Sci. 2014:45:577-620.

190. Hamprecht J, Corsten D, Noll M, Meier E. Controlling the sustainability of food supply chains. Supply Chain Management: An International Journal. 2005;10:7-10. https://doi.org/10.1108/13598540510578315.
191. ETC Group. The Greed Revolution: Mega Foundations, Agribusiness Muscle In On Public Goods. ETC Group, 2012 Contract No.: Issue \#108.

192. Pierce F. Heinz's plans for a European supply chain hub: BizClik media limited; 2020 [14 August 2020]. Available from: https://www. supplychaindigital.com/logistics/heinzs-plans-european-supply-chain-hub.

193. Grimm JH, Hofstetter JS, Sarkis J. Critical factors for sub-supplier management: a sustainable food supply chains perspective. Int J Prod Econ. 2014;152:159-73. https://doi.org/10.1016/j.ijpe.2013.12.011.

194. Lyon JD. Coordinated food systems and accountability mechanisms for food safety: a law and economics approach. Food \& Drug Law Journal. 1998:53:729-75

195. Fold N. Lead firms and competition in 'bi-polar' commodity chains: grinders and branders in the global cocoa-chocolate Industry. J Agrar Chang. 2002;2: 228-47.

196. Friend B, Thompson O. 5th annual: the growing power of mass merchandisers is shifting the requirements of software solutions for food manufacturing. Food Engineering. 2003:34-9.

197. Nollen M. Q4 2011 H.J. Heinz Co Earning Conference Call, Investor and Analyst Meeting. CQ Transcriptions; 2011.

198. Passport. Foodservice as a Tool for Direct-To-Consumer Branding and Innovation. Euromonitor International, 2020.

199. EUR-Lex. Commission Decision of 07/02/2000 declaring a concentration to be compatible with the common market (Case No COMP/M.1683 - THE COCA-COLA COMPANY / KAR-TESS GROUP (HELLENIC BOTTLING)) according to Council Regulation (EEC) No 4064/89. EUR-Lex. 2000.

200. Newswire P. TreeHouse foods sues Green Mountain coffee and Keurig for anticompetitive conduct. PRN: Lawsuit Seeks to Preserve Consumer Choice and Price Competition in K-Cup Market; 2014

201. Mooney P. Blocking the chain: industrial food chain concentration, big data platforms and food sovereignty solutions. ETC Group: Val David, Canada; 2018

202. Willis W. European Commission - concentrations - Nestle's bid tp takeover Perrier: a landmark merger restructuring on duopoly grounds. Journal of International and Competition Law. 1993;141.

203. Strategy B. A fruity brand extension. BRASTR. 2002.

204. ETC Group. Plate tech-tonics: mapping corporate power in big food ETC group, 2019.

205. Passport. Food Faith or Food Fact? The Emergence of Regulation on Processed Food. Euromonitor International, 2019.

206. Abboud L, Terazono E. Cashew foie gras? Big food jumps on 'plant-based' bandwagon: financial Times; 2019 [28 July 2020]. Available from: https:// www.ft.com/content/24660944-786a-11e9-be7d-6d846537acab.

207. EUR-Lex. Commission Decision of 15/02/2002 declaring a concentration to be compatible with the common market (Case No COMP/M.2544 - MAST ERFOODS / ROYAL CANIN) according to Council Regulation (EEC) No 4064/ 89. EUR-Lex. 2002

208. License Global. Eating up the competition: food and beverage licensing: Informa markets; 2018 [14 August 2020]. Available from: https://www. licenseglobal.com/magazine-article/eating-competition-food-and-beveragelicensing.

209. De Barcellos M, Pozzo D, Ferreira G, Lionello R. The dynamics of the innovation system for functional foods in South Brazil. In: Networks IEFoSDaliF, editor. Innsbruck, Austria2011.

210. Hendrickson MK, Heffernan WD. Opening spaces through Relocalization: locating potential resistance in the weaknesses of the global food system. Sociol Rural. 2002:42.

211. Ferguson A. Hard choices for soft drinks. The Weekend Australian. 2008.

212. Gearhardt AN, Grilo CM, DiLeone RJ, Brownell KD, Potenza MN. Can food be addictive? Public health and policy implications. Addiction. 2011;106:120812. https://doi.org/10.1111/j.1360-0443.2010.03301.x

213. Independent Media Institute. Food Companies are Making Their Products Addictive, and It's Sickening (Literally): EcoWatch; 2019 [10 August 2020]. Available from: https://www.ecowatch.com/food-companies-makingproducts-addictive-2632845184.html.

214. Kessler D. Why we overeat. Nutrition Action Health Letter. 2006:3-6.

215. Bhuyan S. An empirical evaluation of factors determining vertical integration in U.S. food manufacturing industries. Agribusiness. 2005;21:429-45. doi: 10. 1002/agr.20056

216. Sojamo S, Larson EA. Investigating food and agribusiness corporations as global water security, management and governance agents: the case of Nestlé. Bunge and Cargill Water Alternatives. 2012;5:619-35. 
217. Statement of Christine A. Varney, Assistant Attorney General, at the Field Hearing, 'Crisis on the Farm: The State of Cooperation and Prospects for Sustainability in the Northeast Dairy Industry': Hearing before the US Department of Justice (2009)

218. Oxfam. Behind the brands: Food justice and the 'Big 10' food and beverage companies. Oxfam, GROW, 2013 Contract No.: 166 Oxfam Briefing Paper.

219. Unterschultz J, Jeffrey S, Quagrainie K. Value-Adding 20 Billion by 2005: Impact at the Alberta Farm Gate. Edmonton, Canada: Department of Rural Economy, University of Alberta, 2000 Contract No.: 980842.

220. Charles D Thanks to Nutella, The World Needs More Hazelnuts: NPR; 2014 [17 August 2020]. Available from: https://www.npr.org/sections/thesalt/ 2014/09/16/347749070/thanks-to-nutella-the-world-needs-more-hazelnuts.

221. Stuart D. Constrained choice and ethical dilemmas in land management: environmental quality and food safety in California agriculture. J Agric Environ Ethics. 2008;22:53-71. https://doi.org/10.1007/s10806-008-9129-2.

222. Wesseler J. Biotechnologies and agrifood strategies: opportunities, threats and economic implications. Bio-based and Applied Economics. 2014;3:187204. doi: 10.13128/BAE-15017.

223. López Rodríguez CM. Enforcing contracts and resolving disputes in contract farming: how ADR can address the specificities of agricultural production contracts. Uniform Law Review - Revue de droit uniforme. 2015;20:180-200. https://doi.org/10.1093/ulr/unv012.

224. Falkowski J, Ménard C, Sexton RJ, Swinnen J, Vandevelde S. Unfair trading practices in the food supply chain. European Commission: Luxembourg; 2017.

225. ACCC. Dairy processors agree to amend farmer contract terms: Australian Competition \& Consumer Commission; 2018 [22 July 2020]. Available from: https://www.accc.gov.au/media-release/dairy-processors-agree-to-amendfarmer-contract-terms.

226. Keogh M. The ACCC view - dairy from a competition perspective transTasman dairy leaders forum: ACCC; 2019. Available from: https://www.accc. gov.au/speech/the-accc-view-dairy-from-a-competition-perspective.

227. Young $L$, Hobbs J. Vertical linkages in Agri-food supply chains: changing roles for producers, commodity groups, and government policy. Rev Agric Econ. 2002;24:428-41.

228. Cante C, Calluzo V, Ryan H. Strategic alliances in the food and beverage Industry. J Bus Econ Res. 2003;1

229. Ross A. Solazyme hits it big in deal with Unilever for algae oil. San Francisco Chronicle. 2013

230. Department of Justice Office of Public Affairs. Justice Department Requires ConAgra, Cargill, CHS, Horizon Milling to Divest Four Significant Flour Mills to Go Forward with Ardent Mills Joint Venture Washington DC: The United States Department of Justice; 2014 [22 July 2020]. Available from: https:// www.justice.gov/opa/pr/justice-department-requires-conagra-cargill-chshorizon-milling-divest-four-significant-flour.

231. Durie J. Davis seeks a level playing field. The Weekend Australian. 2013.

232. European Commission. Green Paper on Unfair Trading Practices in the Business-to-Business Food and Non-food Supply Chain in Europe. European Commission, 2013 Contract No.: COM(2013)37

233. Burch D, Lawrence G. Supermarket own brands, supply chains and the transformation of the Agri-food system. International Journal of Sociology of Agriculture and Food. 2005;13.

234. Yancey A, Cole B, Brown R, Williams J, Hillier A, Kline R, et al. A crosssectional prevalence study of ethnically targeted and general audience outdoor obesity-related advertising. The Millbank Quarterly. 2009;87:155-84.

235. POM Wonderful LLC v. Coca-Cola Co. Kennedy, J: Supreme Court of the United States; 2014.

236. Unilever and Smith's pay penalties for misleading healthy food representations [press release]. Australian Competition and Consumer Commission2016.

237. Court finds Heinz made a misleading health claim [press release]. Australian Competition and Consumer Commission2018.

238. Jones S. Fat free and 100\% natural: seven food labelling tricks exposed: the conversation; 2014 [10 August 2020]. Available from: https:// theconversation.com/fat-free-and-100-natural-seven-food-labelling-tricksexposed-25143.

239. EUR-Lex. Commission Decision of 27/09/2012 declaring a concentration to be compatible with the common market (Case No COMP/M.661 - ARLA FOODS / MILK LINK) according to Council Regulation (EC) No 139/2004. EUR-Lex. 2012.

240. Service RN. Kraft Foods Inc. RNS: Offer by Kraft Foods Inc. for Cadbury PLC 2009.
241. Interbrand. Best Global Brands 2019 Rankings 2020. Available from: https:// www.interbrand.com/best-brands/best-global-brands/2019/ranking/.

242. Gasparon P, Višnar B. Coca-Cola: Europe-wide remedies in fizzy drinks. 2005 Contract No.: 3.

243. Marketing Week. Kellogg in Aldi own-label deal: centaur media PLC; 2000 [3 November 2020]. Available from: https://www.marketingweek.com/kelloggin-aldi-own-label-deal-2/.

244. Kanter J. EU and Coca-Cola new antitrust accord - agreement would increase visibility of competitors to soft-drinks company. Wall Street J. 2004.

245. Hastings G. Why corporate power is a public health priority. BMJ. 2012;345: e5124. https://doi.org/10.1136/bmj.e5124.

246. Investopedia. A Look at Coca-Cola's Advertising Expenses: Dotdash; 2020 [3 December 2020]. Available from: https://www.investopedia.com/articles/ markets/081315/look-cocacolas-advertising-expenses.asp\#: :text=The\%2 Ocompany\%20spent\%20roughly\%20\%244.25 ,advantage\%20in\%20several\%20key\%20areas.

247. Organization WH. Overview of financial situation: Programme budget 2018 2019. Seventy-second World Health Assembly, 2019 Contract No.: A72/34.

248. Akerlof G, Shiller R. Manipulation and deception as part of a phishing equilibrium. Bus Econ. 2016;51:217-2.

249. Food Processing. How food and beverage brands have been responding to anti-racism movement 2020 [3 December 2020]. Available from: https:// www.foodprocessing.com/industrynews/2020/food-and-beverage-brandsresponding-to-anti-racism/.

250. Collin J, Rolston R, Hill S, Westerman L. Signalling virtue, promoting harm: unhealthy commodity industries and COVID-19. SPECTRUM: NCD Alliance; 2020.

251. Global Health Advocacy Incubator. Facing two pandemics: how big food undermined public health in the era of COVID-19. Washington, DC: Campaign for Tobacco-Free Kids; 2020.

252. Swinburn B, Sacks G, Hall K, McPherson K, Finegood D, Moodie M, et al. The global obesity pandemic: shaped by global drivers and local environments. Lancet. 2011;378:804-14.

253. Tilman D, Clark M. Global diets link environmental sustainability and human health. Nature. 2014;515:518-22. https://doi.org/10.1038/nature13959.

254. Lang T, Heasman M. Food wars: the global battle for mouths, minds and markets. Second edition. London and New York: Routledge; 2014.

255. Hendrickson MH, Philip; Constance, Douglas;. Power, food and agriculture: implications for farmers, consumers and communities. In: Missouri Uo, editor. Division of Applied Social Sciences Working Paper2017.

256. Scrinis G. Nutritionism : the science and politics of dietary advice. New York: Columbia University Press; 2013. vi, 352 pages $p$

257. HLPE. Nutrition and food systems. A report by the High Level Panel of Experts on Food Security and Nutrition of the Committee on World Food Security. Rome: 2017.

258. Hawkes $C$. The role of foreign direct investment in the nutrition transition. Public Health Nutr. 2005;8. https://doi.org/10.1079/phn2004706.

259. Hawkes C, Thow AM. Implications of the Central America-Dominican Republic-free trade agreement for the nutrition transition in Central America. Pan Am J Public Health. 2008:24:345-60.

260. Oaks KL. The public value of ecological agriculture. Vermont Journal of Environmental Law. 2020;21.

261. Thow AM, Downs SM, Mayes C, Trevena H, Waqanivalu T, Cawley J. Fiscal policy to improve diets and prevent noncommunicable diseases: from recommendations to action. Bull World Health Organ. 2018;96:201-10. https://doi.org/10.2471/BLT.17.195982.

262. National MJ, Embeddedness I. The political power of global corporations. Cambridge, UK: Polity Press; 2018.

263. UNCTAD. Cross-border anticompetitive practices: The challenges for developing countries and economies in transition. Geneva, Switzerland: United Nations Conference on Trade and Development, 2012 Contract No: TD/B/C.I/CLP/16

264. Arora NK, Pillai R, Dasgupta R, Garg PR. Whole-of-society monitoring framework for sugar, salt, and fat consumption and noncommunicable diseases in India. Ann N Y Acad Sci. 2014;1331:157-73. https://doi.org/10. 1111/nyas.12555.

265. Seifullaeva M, Shirochenskaya I, Shklyar T, Mkhytaryan S, Panasenko S. Strategy of import substitution in Russian food market. International Journal of Economic Perspectives. 2017;11:1397-406.

266. Lund J, Wright C. Integrating the supply chain: industrial relations implications in US grocery distribution. N Technol Work Employ. 2003;18: 101-14. 
267. Bauner C, Lavoie N, Rojas C. Effects of technological progress on vertical product differentiation and welfare. Eur Rev Agric Econ. 2017;44:67-97. https://doi.org/10.1093/erae/jbw012.

268. OECD. Cross-Border Merger Control: Challenges for Developing and Emerging Economies. Organisation for Economic Co-operation and Development, 2011 Contract No.: DAF/COMP/GF(2011)13.

269. IPES-Food. Towards a Common Food Policy for the European Union. International Panel of Experts on Sustainable Food Systems, 2019.

270. Wardle J, Baranovic M. Is lack of retail competition in the grocery sector a public health issue? Aust N Z J Public Health. 2009;33:477-81. https://doi. org/10.1111/j.1753-6405.2009.00433.x.

271. Clapp J. Mega-mergers on the menu: corporate concentration and the politics of sustainability in the global food system. Global Environmental Politics. 2018;18:12-33. https://doi.org/10.1162/glep_a_00454.

272. Fair Trade Advocacy Office. EU competition law and sustainability in food systems: addressing the broken links. Brussels: 2019.

273. Lianos I, Darr A. Hunger games: connecting the right to food and competition law. In: Faculty of Law U, editor. CLES Research Paper Series. London2019.

274. De Schutter O. Addressing Concentration in Food Supply Chains: The Role of Competition Law in tackling the Abuse of Buyer Power. In: Food SRotRt editor. Briefing Note 032010.

275. American Chamber of Commerce to the European Union. Discriminatory taxation of food and beverages is ineffective and distorts competition. Brussels, Belgium: 2012.

276. Coyne E. Sugar tax 'would breach EU competition law'. The Times. 2017.

277. Byrne J. Confectionery tax will distort competition, claims Finnish industry body: confectionery News; 2010 [7 December 2020]. Available from: https:// www.confectionerynews.com/Article/2010/09/23/Confectionery-tax-willdistort-competition-claims-Finnish-industry-body.

278. European Commission. State aid: commission clears Ireland's sugar sweetened drinks tax 2018 [7 December 2020]. Available from: https://ec. europa.eu/ireland/news/commission-clears-irelands-sugar-sweetened-drinkstax_en.

279. Parsons K, Hawkes C. Connecting food systems for co-benefits: how can food systems combine diet-related health with environmental and economic policy goals? WHO Regional Office for Europe: Copenhagen, Denmark; 2018

280. Pingali P. Agricultural policy and nutrition outcomes - getting beyond the preoccupation with staple grains. Food Security. 2015;7:583-91. https://doi. org/10.1007/s12571-015-0461-x.

281. Sacks G. Policies for tackling obesity and creating healthier food environments: Scorecare and priority recommendations for Australian governments. Melbourne: Deakin University and the Obesity Coalition Australia; 2017.

282. World Cancer Research Fund International. NOURISHING framework: WCRF; 2020 [28 August 2020]. Available from: https://www.wcrf.org/int/policy/ policy-databases/nourishing-framework.

283. European Heart Network. Transforming European food and drink policies for cardiovascular health. Brussels, Belgium: EHN, 2017.

284. Savell E, Fooks G, Gilmore AB. How does the alcohol industry attempt to influence marketing regulations? A systematic review. Addiction. 2016;111: 18-32. https://doi.org/10.1111/add.13048.

285. Savell E, Gilmore AB, Fooks G. How does the tobacco industry attempt to influence marketing regulations? A systematic review PLoS One. 2014;9: e87389. https://doi.org/10.1371/journal.pone.0087389.

286. Ulucanlar S, Fooks GJ, Gilmore AB. The policy dystopia model: an interpretive analysis of tobacco Industry political activity. PLoS Med. 2016;13: e1002125. https://doi.org/10.1371/journal.pmed.1002125.

287. Eastmure E, Cummins S, Sparks L. Non-market strategy as a framework for exploring commercial involvement in health policy: a primer. Soc Sci Med. 2020;262:113257. https://doi.org/10.1016/j.socscimed.2020.113257.

288. Lamberg J-A, Skippari M, Eloranta J, MÄKinen S. The evolution of corporate political action: a framework for Processual Analysisx. Bus Soc. 2016;43:33565. https://doi.org/10.1177/0007650304272241

289. Hawkins B, Holden C, Eckhardt J, Lee K. Reassessing policy paradigms: a comparison of the global tobacco and alcohol industries. Glob Public Health. 2018;13:1-19. https://doi.org/10.1080/17441692.2016.1161815.

290. Freudenberg N. The manufacture of lifestyle: the role of corporations in unhealthy living. J Public Health Policy. 2012;33:244-56. https://doi.org/10. 1057/jphp.2011.60
291. Kickbusch I, Allen L, Franz C. The commercial determinants of health. Lancet Glob Health. 2016;4:e895-e6. https://doi.org/10.1016/s2214-109x(16)30217-0.

292. Baum FE, Sanders DM, Fisher M, Anaf J, Freudenberg N, Friel S, et al. Assessing the health impact of transnational corporations: its importance and a framework. Glob Health. 2016;12:27. https://doi.org/10.1186/s12992016-0164-X

293. Walls H, Cook S, Matzopoulos R, London L. Advancing alcohol research in low-income and middle-income countries: a global alcohol environment framework. BMJ Glob Health. 2020;5:e001958. https://doi.org/10.1136/ bmjgh-2019-001958.

294. Madureira Lima J, Galea S. Corporate practices and health: a framework and mechanisms. Glob Health. 2018;14. https://doi.org/10.1186/s12992-018-0336y.

295. Holden C, Lee K. Corporate power and social policy: the political economy of the transnational tobacco companies. Glob Soc Policy. 2009;9:328-54. https://doi.org/10.1177/1468018109343638.

296. Mialon M, Swinburn B, Wate J, Tukana I, Sacks G. Analysis of the corporate political activity of major food industry actors in Fiji. Glob Health. 2016;12:18. https://doi.org/10.1186/s12992-016-0158-8.

297. Mialon M, Mialon J. Analysis of corporate political activity strategies of the food industry: evidence from France. Public Health Nutr. 2018;21:3407-21.

298. Mialon M, da Silvia Gomes F. Public health and the ultra-processed food and drink products industry: corporate political activity of major transnationals in Latin America and the Caribbean. Public Health Nutr. 2019; 22:1898-908.

299. Mialon M, Swinburn B, Allender S, Sacks G. Systematic examination of publicly-available information reveals the diverse and extensive corporate political activity of the food industry in Australia. BMC Public Health. 2016; 16:283. https://doi.org/10.1186/s12889-016-2955-7.

\section{Publisher's Note}

Springer Nature remains neutral with regard to jurisdictional claims in published maps and institutional affiliations.
Ready to submit your research? Choose BMC and benefit from:

- fast, convenient online submission

- thorough peer review by experienced researchers in your field

- rapid publication on acceptance

- support for research data, including large and complex data types

- gold Open Access which fosters wider collaboration and increased citations

- maximum visibility for your research: over $100 \mathrm{M}$ website views per year

At $\mathrm{BMC}$, research is always in progress.

Learn more biomedcentral.com/submissions 